\title{
Multi-Protein Dynamic Combinatorial Chemistry: A Novel Strategy that Leads to Simultaneous Discovery of Subfamily-Selective Inhibitors for Nucleic Acid Demethylases FTO and ALKBH3
}

\author{
Mohua Das, Tianming Yang, Jinghua Dong, Fransisca Prasetya, Yiming Xie, Kendra H. Q. Wong, \\ Adeline Cheong, and Esther C. Y. Woon*[a]
}

\begin{abstract}
Dynamic combinatorial chemistry (DCC) is a powerful supramolecular approach for discovering ligands for biomolecules. To date, most, if not all biologically-templated DCC employ only a single biomolecule in directing the self-assembly process. To expand the scope of DCC, herein, we developed a novel multi-protein DCC strategy which combines the discriminatory power of zwitterionic 'thermal-tag' with the sensitivity of differential scanning fluorimetry. This strategy is highly sensitive and could differentiate the binding of ligands to structurally-similar subfamily members. Through this strategy, we were able to simultaneously identify subfamily-selective probes against two clinically-important epigenetic enzymes, FTO (7; $\left.I_{50}=2.6 \mu \mathrm{M}\right)$ and $\operatorname{ALKBH} 3\left(8 ; I C_{50}=3.7 \mu \mathrm{M}\right)$. To our knowledge, this is the first report of a subfamily-selective ALKBH3 inhibitor. The developed strategy could, in principle, be adapted to a broad range of proteins, thus it shall be of broad scientific interest.
\end{abstract}

\section{Introduction}

Dynamic combinatorial chemistry (DCC) is a powerful supramolecular approach for discovering ligands for biological targets. The idea was first independently conceived and developed by the Sanders and Lehn groups (for excellent reviews see Refs 1-10). ${ }^{[1-10]}$ In the DCC method, simple building blocks are linked together by reversible covalent chemistry to generate dynamic libraries of structures. Because of the reversible nature of these libraries, they are highly responsive to external influence, such that the introduction of a template triggers rapid structural adaptation of the library members, resulting in the assembly of structures that are highly complementary to the template. To date, DCC has been successfully applied to a range of biological templates, including enzymes, receptors, transmembrane transporters, nucleotides, and polymer-supported targets. ${ }^{[11-17]}$ However, most, if not all, such biologically-templated DCC

[a] M. Das, Dr. T. Yang, J. Dong, F. Prasetya, Y. Xie, K. H. Q. Wong, A. Cheong, Asst. Prof. E. C. Y. Woon*

Department of Pharmacy

National University of Singapore

18 Science Drive 4, Singapore 117543

E-mail: esther.woon@nus.edu.sg

Supporting information for this article is given via a link at the end of the document. approaches employ only a single template in directing the selfassembly process; this severely limits the applications of DCC approaches.

To expand the scope and potential of DCC, in this study, we explored the concept of multi-protein DCC, where two or more protein templates were used concurrently in the same dynamic system. We envisaged that such a strategy would enable the discovery of ligands against several proteins of interest simultaneously, thus greatly multiply the power and efficiency of DCC. Another distinct advantage of the multi-protein DCC approach is that it permits the use of several structurally and/or functionally related protein isoforms in concert. This ensures that only ligands that are highly selective for a particular protein isoform or target will be assembled and identified. Although it is also possible to achieve highly selective inhibition from conventional DCC approaches (for instance, Greaney et al. ${ }^{[18]}$ successfully identified isozyme-selective glutathione $S$ transferases inhibitors using an acyl hydrazone-based DCC), single-templated DCC only generate hits against one target at a time.

The development of the proposed multi-protein DCC system poses a number of analytical challenges. Not only is there a requirement to analyse several protein-ligand interactions simultaneously, it is also necessary to assign binding of ligands to specific proteins in a complex, multi-component mixture. Furthermore, structures generated from reversible self-assembly system are constantly exchanging, and this further complicates their analysis.

Currently, only few methods have been reported for the analysis of single-templated DCC, ${ }^{[8,19]}$ this include HPLC analysis, ${ }^{[20,21]}$ NMR studies, ${ }^{[22-24]}$ X-ray crystallography, ${ }^{[25]}$ size-exclusion chromatography $(\mathrm{SEC})^{[26,27]}$ and, more recently, the use of polymer-scaffolded (PS-DCL), ${ }^{[28]} \mathrm{DNA}^{[29-32]}$ or peptide nucleic acids (PNA)-encoded ${ }^{[33,34]}$ DCC libraries. However these methods only detect amplification of the best binders in the presence of the template, and could not distinguish which template is responsible for the observed amplification, hence they are unsuitable for the proposed multi-protein DCC system. Although it is possible to directly observe different protein-ligand complexes using native protein mass spectrometric (MS) techniques, the results of MS analyses are not always representative of what exists in solution, since different non-covalent complexes survive the transition from solution to gas phase differently. ${ }^{[35]}$ Indeed, our group ${ }^{[14]}$ and that 


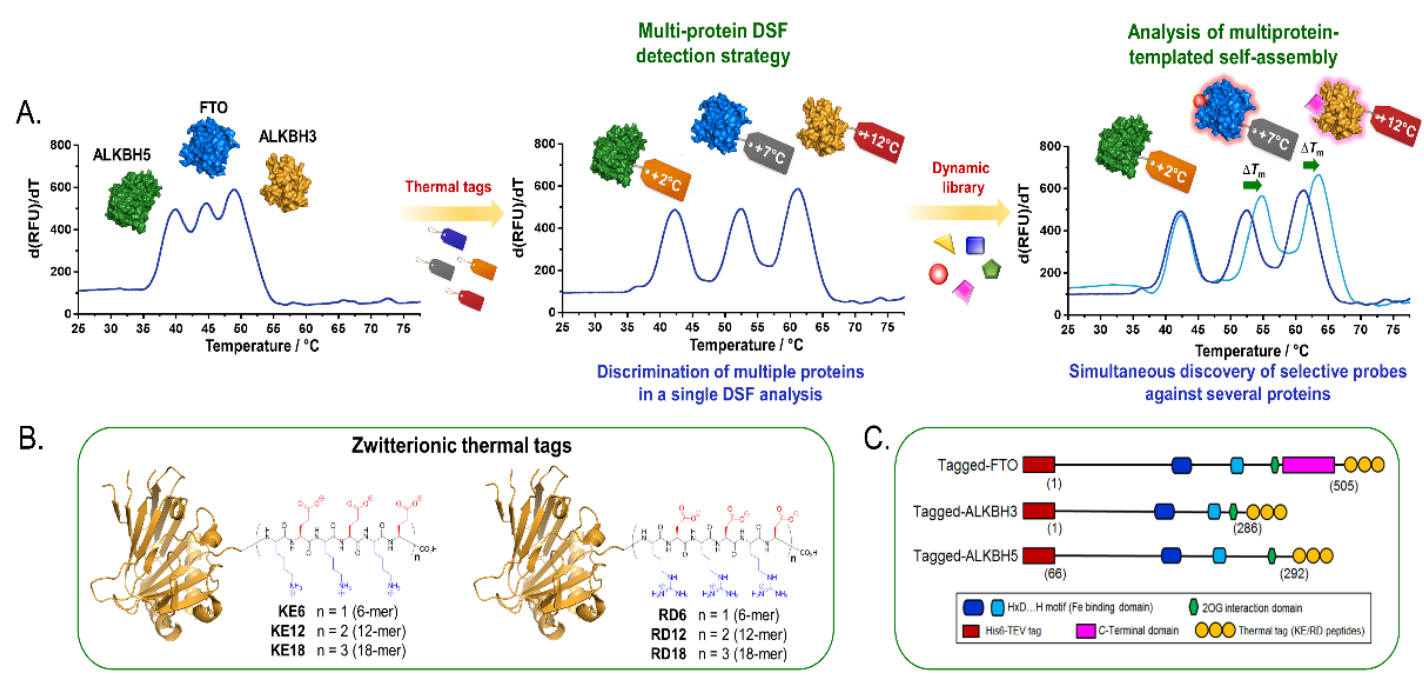

Figure 1. The multi-protein DSF detection strategy and its application on dynamic self-assembly system. (A) In this approach, 'thermal tags' which, by design, are capable of exclusively modulating the melting temperature of fusion partner proteins without compromising their structures and functions are used to fine-tune the melting temperature of the target proteins, such that their individual melting profiles could be simultaneously monitored in a single DSF melting analysis. When used in combination with DCC, formation of stable protein-ligand complexes can be easily detected by shifts in $\mathrm{T}_{\mathrm{m}}$ of proteins engaged in ligand binding. (B) Structures of thermal tags investigated in this study. Both the KE and RD tags are zwitterionic peptides with alternating positively (blue) and negatively (red) charged amino acids. (C) Schematic diagram of the fusion constructs. The KE or RD tag was genetically appended to the C-terminus of FTO, ALKBH3 and ALKBH5, which are clinically-important proteins belonging to the iron- and 2-oxoglutarate (2OG)-dependent AlkB oxygenases. The starting and terminating residue numbers of the proteins are given in parentheses. The fusion constructs also contain N-terminus His6-TEV tag to facilitate protein purification (for details of expression and purification of the fusion proteins, see Supporting Information)

of Poulsen ${ }^{[36]}$ have previously observed fragmentation of proteinligand complexes under certain MS ionisation conditions. To date, no method exists which allow the analysis of multiple proteinligand interactions in a dynamic system. This severely limits the potential applications of DCC-based approaches.

Recent studies demonstrated that zwitterionic polymers, in general, are able to confer a wide range of biophysical properties when conjugated to proteins, such as increased water solubility, $\mathrm{pH}$ resistance, and antifouling property. ${ }^{[37-40]}$ More recently, Jiang et al. showed that poly(carboxybetaine) polymers and poly(Glu-Lys) polypeptides were able to improve the thermal stability of fusion partner proteins, rendering them more resistant to heat inactivation. ${ }^{[41,42]}$

Inspired by these interesting observations, herein, we present a novel detection strategy, which enables the simultaneous analysis of several protein-ligand complexes in a multi-protein DCC system (Figure 1A). It combines the discriminatory power of 'thermal tag' with the sensitivity of differential scanning fluorimetry (DSF) technique. In this approach, the proteins of interest are genetically labelled with a zwitterionic peptide-based thermal tags, which by design are capable of modifying the thermal stability of the host proteins without disrupting their structural and functional properties. The expectation is that, by appending appropriate thermal tags, one could specifically fine-tune the melting temperatures $\left(T_{\mathrm{m}}\right)$ of the proteins such that their individual melting profiles could be simultaneously monitored in a single DSF melting analysis. When used in combination with DCC, formation of protein-ligand complexes can be easily detected by an increase in $T_{\mathrm{m}}$ of the proteins that are engaged in ligand binding.
This approach is conceptually similar to DSF-based 'thermal shift assay' which has been widely used for the detection of proteinligand interactions with stable ligands. ${ }^{[43]}$ However, prior to this work, it is not known whether DSF could be applied to the analysis of dynamic library. We are also not aware of the combined use of 'thermal tag' with DSF to facilitate the study of multiple proteinligand interactions. As we shall demonstrate, multi-protein DSF is a simple, yet powerful strategy for monitoring protein-templated self-assembly. Through this method, one is able to assess $T_{\mathrm{m}}$ shift and thermodynamic parameters of an equilibrating system in a single, rapid DSF experiment. We further provide proof of principle that the combined use of multi-protein DSF strategy and DCC can enable simultaneous templating of several target proteins. This is demonstrated by the concurrent discovery of subfamily-selective inhibitors against two clinically-important epigenetic enzymes, FTO and ALKBH3.

To the best of our knowledge, the present study represents not only the first report of multi-protein DCC method, but also a new strategy for probing dynamic chemical systems, which hopefully will further our understanding of protein-directed self-assembly, and inspire new applications for DCC-based approaches.

\section{Results and Discussion}

\section{Thermal tag design and protein engineering}

In this study, we selected three members of the iron- and 2-oxoglutarate (2OG)-dependent AlkB oxygenases, namely FTO, ALKBH3 and ALKBH5, as our protein templates. ${ }^{[4]}$ These AlkB proteins are currently of intense biological and medical interest 
Table 1. Thermal stability data for ALKBH5, FTO, ALKBH3, and their corresponding KE- and RD-tagged fusion proteins ${ }^{[a]}$

\begin{tabular}{|l|c|c|c|c|c|c|}
\hline \multirow{2}{*}{$\begin{array}{c}\text { Thermal } \\
\text { tag }\end{array}$} & \multicolumn{2}{|c|}{ ALKBH5 } & \multicolumn{2}{c|}{ FTO } & \multicolumn{2}{c|}{ ALKBH3 } \\
\cline { 2 - 7 } & $\boldsymbol{T}_{\mathrm{m}}\left({ }^{\circ} \mathrm{C}\right)^{\mathrm{a}}$ & $\Delta T_{\mathrm{m}}\left({ }^{\circ} \mathrm{C}\right)^{\mathrm{a}}$ & $T_{\mathrm{m}}\left({ }^{\circ} \mathrm{C}\right)^{\mathrm{a}}$ & $\Delta T_{\mathrm{m}}\left({ }^{\circ} \mathrm{C}\right)^{\mathrm{a}}$ & $T_{\mathrm{m}}\left({ }^{\circ} \mathrm{C}\right)^{\mathrm{a}}$ & $\Delta T_{\mathrm{m}}\left({ }^{\circ} \mathrm{C}\right)^{\mathrm{a}}$ \\
\hline Untagged & $40.3 \pm 0.1$ & -- & $45.1 \pm 0.2$ & -- & $49.4 \pm 0.3$ & -- \\
\hline KE6 & $42.4 \pm 0.2$ & 2.1 & $48.3 \pm 0.1$ & 3.2 & $53.6 \pm 0.1$ & 4.2 \\
\hline KE12 & $45.2 \pm 0.2$ & 4.9 & $52.6 \pm 0.2$ & 7.5 & $57.4 \pm 0.1$ & 8.0 \\
\hline KE18 & $49.5 \pm 0.3$ & 9.2 & $55.4 \pm 0.3$ & 10.3 & $61.7 \pm 0.1$ & 12.3 \\
\hline RD6 & $42.1 \pm 0.2$ & 1.8 & $47.8 \pm 0.1$ & 2.7 & $52.5 \pm 0.3$ & 3.1 \\
\hline RD12 & $43.7 \pm 0.1$ & 3.4 & $49.7 \pm 0.1$ & 4.6 & $53.2 \pm 0.1$ & 3.8 \\
\hline RD18 & $48.5 \pm 0.2$ & 8.2 & $53.3 \pm 0.2$ & 8.2 & $57.9 \pm 0.2$ & 8.5 \\
\hline
\end{tabular}

[a]The $\mathrm{Tm}$ values of the fusion proteins were measured at a protein concentration of $2 \mu \mathrm{M}$ (in $50 \mathrm{mM}$ HEPES buffer, $\mathrm{pH}$ 6.0) using DSF melting analysis.

because of their critical roles in several key cellular processes, such as epigenetic gene regulation and RNA metabolism. ${ }^{[45-47]}$ It is also increasingly clear that dysregulation of these enzymes may underlie the pathogenesis of a range of human diseases, including metabolic diseases, neurodegenerative diseases and cancers. ${ }^{[48-51]}$ However, despite their clinical significance, to date, there have only been few reports of inhibitors that selectively target these enzymes, in part due to their close structural similarity, which renders the development of subfamily-selective inhibitors particularly challenging. In this regard, the selection of AlkB subfamilies for the present study not only allows us to 1) evaluate the power of multi-protein DCC strategy to simultaneously discover probes against several clinically-important targets, but also 2 ) its potential in directing the self-assembly of probes with subfamily-selectivity.

To implement the proposed strategy (Figure 1A), we first designed a series of thermal tags that are capable of conferring different melting temperatures to the AlkB proteins. As potential candidates, we considered short zwitterionic peptides, that are 6 , 12 or 18 residues in length, with either alternating Lys/Glu (KE) sequences (abbreviated as KE6-, KE12-, and KE18-tags) or alternating Arg/Asp (RD) sequences (abbreviated as RD6-, RD12-, and RD18-tags) (Figure 1B). Recent studies suggested that zwitterionic polymers such as poly(carboxybetaine) polymers and poly(Glu-Lys) polypeptides can increase the thermal resistance of fusion partner proteins. ${ }^{[41,42]}$ However, we are not aware of the use of zwitterionic peptides to specifically modulate the melting temperature of proteins. The effect of zwitterionic peptides on the melting behaviour of proteins has also not been systematically studied.

To investigate the suitability of zwitterionic peptides as thermal tags, the KE and RD sequences were genetically appended to the $C$-terminus of FTO, ALKBH3 and ALKBH5 using protein engineering techniques; modelling analysis suggests that fusion of a relatively short peptide to the $C$-terminus of AlkB subfamilies is likely to be minimally disruptive on the structure and function of the protein (Figure 1C, for details of gene constructs and protein expression, see Supporting Information). Successful expression of all recombinant fusion proteins was confirmed by SDS-PAGE and ESI-MS analyses (Figure S1).
Introduction of a single thermal tag triggered dramatic increase in the thermal stability and melting temperature of the AlkB subfamilies

We initially investigated the impact of thermal tags on protein melting characteristics. DSF-based melting analyses showed that all KE-tagged and RD-tagged ALKBH5 fusion proteins unfold cooperatively to produce monophasic melting transitions similar to that observed with unmodified ALKBH5, implying that the proteins remained stably folded when conjugated with KE or RD tag (Figures $2 \mathrm{~A}$ and $\mathrm{S} 2 \mathrm{~A}$ ). The melting temperatures of the ALKBH5 fusion proteins are however significantly higher than that of unmodified ALKBH5 ( $T_{\mathrm{m}}=40.3 \pm 0.1^{\circ} \mathrm{C}$; Table 1$)$, suggesting a marked improvement in their thermal stability. The extent of thermal stabilisation appears to be dependent on the length of the thermal tag used, as demonstrated by observation that relatively short KE6 tag increases the $T_{\mathrm{m}}$ of ALKBH5 by $2.1^{\circ} \mathrm{C}$, whilst longer KE12 and KE18 tags triggered a more dramatic $T_{\mathrm{m}}$ increase of $4.9{ }^{\circ} \mathrm{C}$ and $9.2{ }^{\circ} \mathrm{C}$, respectively. Similar trend (i.e. longer tag leading to larger $T_{\mathrm{m}}$ increase) was also observed with $\mathrm{RD}$ tags, although correspondingly smaller $T_{\mathrm{m}}$ increases of $1.8^{\circ} \mathrm{C}$, $3.4{ }^{\circ} \mathrm{C}$ and $8.2^{\circ} \mathrm{C}$ were produced by RD6, RD12 and RD18 tags, respectively. Thus the $\mathrm{RD}$ tags are slightly less effective in improving protein thermal stability than KE tags of the same length.

Interestingly, the thermal stabilisation effect of KE and RD tags also extends to other AlkB subfamilies, such as FTO and ALKBH3, where modification of both proteins with either KE or RD tag again triggered remarkable increase in their $T_{\mathrm{ms}}$ (Figures 2 and S2). As observed for ALKBH5, FTO and ALKBH3 containing longer tags exhibited a larger $T_{\mathrm{m}}$ increase than their counterparts with shorter tags (Table 1). However, KE tag of the same length appears to have a greater impact on ALKBH3 than on FTO and ALKBH5. For instance, KE18 tag produced a $T_{\mathrm{m}}$ increase of $12.3^{\circ} \mathrm{C}$ in ALKBH3, but only $10.3{ }^{\circ} \mathrm{C}$ in FTO, and $9.2{ }^{\circ} \mathrm{C}$ in ALKBH5 (Table 1). In contrast, RD tag of the same length triggered a similar $T_{\mathrm{m}}$ increase in all three proteins.

These findings are notable because it suggests that the attachment of a single KE or RD tag as short as six residues in length is sufficient to induce a considerable change in the thermal stability and melting temperature of the fusion protein. It further suggests that one can, in principle, fine-tune the melting temperature of AlkB subfamilies by incorporating KE or RD tag of appropriate length. The mechanism by which the KE/RD-tags enhances the melting temperatures of their partner proteins is unclear at present, nevertheless, it has been suggested that zwitterionic peptide, being strongly hydrophilic in nature, has the propensity to pull water away from the hydrophobic regions of the protein. ${ }^{[41,42]}$ Presumably this stabilises the protein folded structures and thus increases its thermal stability and melting temperature. Alternatively, it could also result from ionic interaction between the protein and the zwitterionic tag or a change in the oligomerisation state of the fusion protein. Further studies are needed to understand the underlying mechanisms. 
The thermal tags have little impact on the overall conformation of the AlkB subfamilies

Intriguingly, despite having a profound impact on thermal stability, the thermal tags do not significantly alter the overall secondary structures of the AlkB subfamilies, as clearly demonstrated by far-UV circular dichroism (CD) spectroscopy. In particular, all KEand RD-tagged ALKBH5 share well-ordered secondary structure elements, with a positive maximum at $\sim 194 \mathrm{~nm}$ and a negative band at $\sim 215 \mathrm{~nm}$, which are similar to that observed for unmodified ALKBH5 (Figures 2D and S2D). Spectral fitting further indicates approximately equal $\alpha$-helical $(\sim 24-27 \%)$ and $\beta$-sheet contents $(\sim 26-28 \%)$ in all ALKBH5 fusion proteins, in agreement with the reported X-ray crystal structure of native ALKBH5 (PDB ID: 4NJ4). ${ }^{[52]}$ Similarly, the $C D$ characteristics and secondary structure contents of FTO and ALKBH3 fusion proteins are also highly consistent with that of their unmodified equivalents, suggesting that all thermally-tagged proteins continued to adopt a natively folded conformations (Figures 2E,F and S2; PDB ID: $4 \mathrm{CXW}^{[53]}$ and $\left.2 \mathrm{IUW}^{[54]}\right)$.
The thermal tags do not alter the catalytic activity of the AlkB subfamilies

We were also able to demonstrate that the thermal tags have little impact on the catalytic activities of AlkB demethylases. Notably, ALKBH5 and FTO preferentially demethylate $N^{6}$-methyladenosine $\left(\mathrm{m}^{6} \mathrm{~A}\right)$ substrates, whilst ALKBH3 favours $N^{1}$-methyladenosine $\left(\mathrm{m}^{1} \mathrm{~A}\right)$ substrates. ${ }^{[55,56]}$ Consistent with their inherent substrate specificity, detailed kinetic analyses revealed that ALKBH5 and FTO modified with either KE or RD tag displayed similar affinities $\left(K_{\mathrm{m}}\right)$ and catalytic efficiencies $\left(k_{\text {cat }} / K_{\mathrm{m}}\right)$ for $m^{6} A$ substrate as their unmodified proteins (Figures 2G,H and $\mathrm{S} 2$ ), whilst $\mathrm{ALKBH} 3$ conjugated with either $\mathrm{KE}$ or $\mathrm{RD}$ tag retained $>90 \%$ of its canonical demethylase activity against $\mathrm{m}^{1} \mathrm{~A}$ substrate (Figures $2 \mathrm{I}$ and S2I). This finding is interesting because, contrary to our result, previous study showed that the attachment of larger zwitterionic peptides, such as poly(Glu-Lys) $10 \mathrm{KDa}$ and $30 \mathrm{KDa}$ in length, in fact led to significant increase in the substrate affinities of $\beta$-lactamases. ${ }^{[42]}$ Apparently the greater number of charged residues in longer peptides confer stronger hydrophilic properties which promotes hydrophobic interactions between the substrate and its binding site. Our result therefore suggests that the effects
A
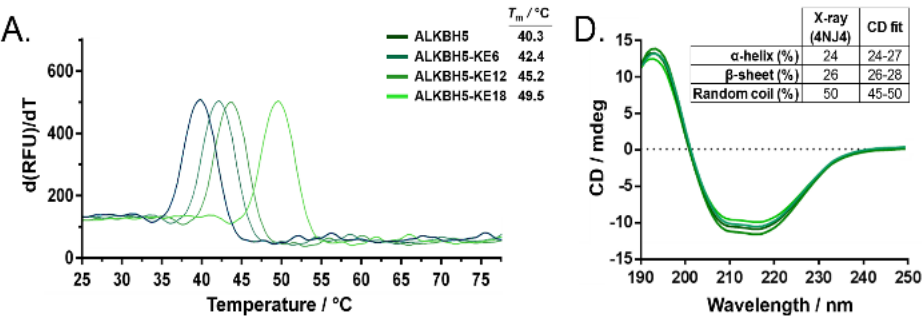

B.
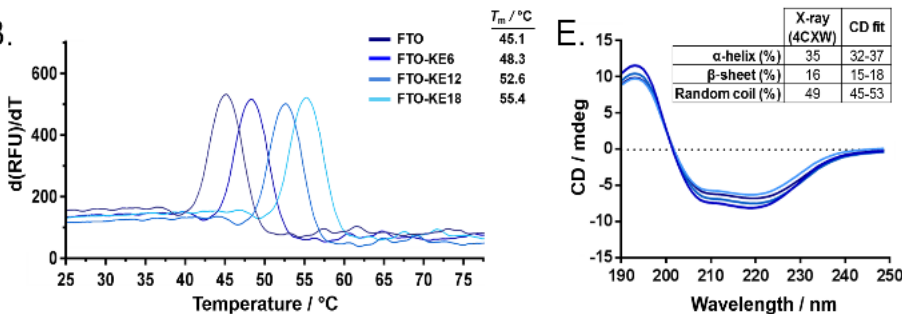

C.

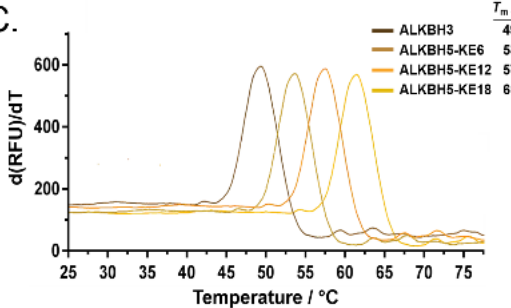

$\mathrm{F}$.

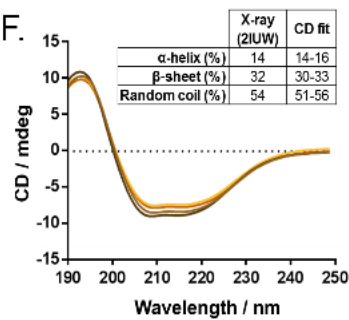

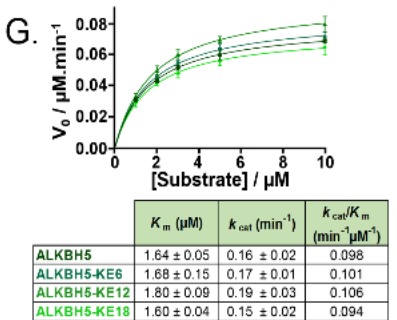
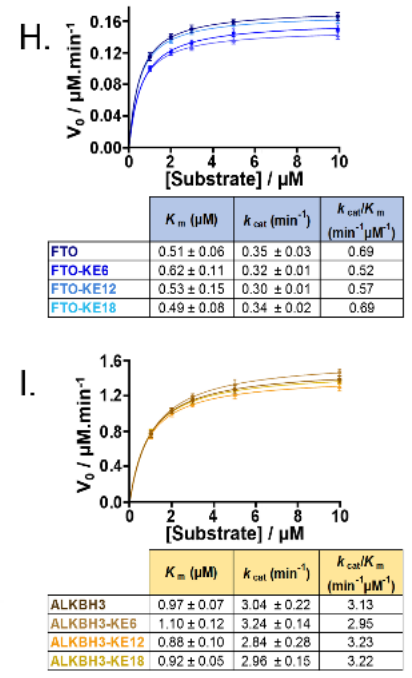

Figure 2. Effects of KE thermal tags on the thermal stability, structural conformation, and catalytic activity of AlkB demethylases (for the effects of RD thermal tags, see Figure. S2). Representative first derivative plots showing the melting profiles of (A) ALKBH5, (B) FTO, and (C) ALKBH3 and their corresponding KE-tagged fusion proteins (colour-coded) at a protein concentration of $2 \mu \mathrm{M}$. In all cases, introduction of a single KE tag triggered a significant increase in the melting temperature of the proteins. The extent of thermal stabilisation increases with the length of the thermal tag used. (D-F) Superimposition of representative far UV-CD spectra for KE-tagged proteins and native proteins reveals negligible conformational change in the presence of the KE tags. The inset shows the secondary structure contents of the fusion proteins derived from CD spectra fit, which are highly consistent with that of native proteins (obtained from X-ray crystal structures), suggesting that the fusion proteins remained natively folded when conjugated with KE tags. (G-I) Steady-state kinetic analyses indicate that modification with KE tag does not significantly alter the binding affinities and the demethylase activities of AlkB enzymes. The $K_{m}$ and $k_{\text {cat }}$ values were determined by keeping a constant enzyme concentration of $0.5 \mu \mathrm{M}$. Error bars represent SD of three replicates. 


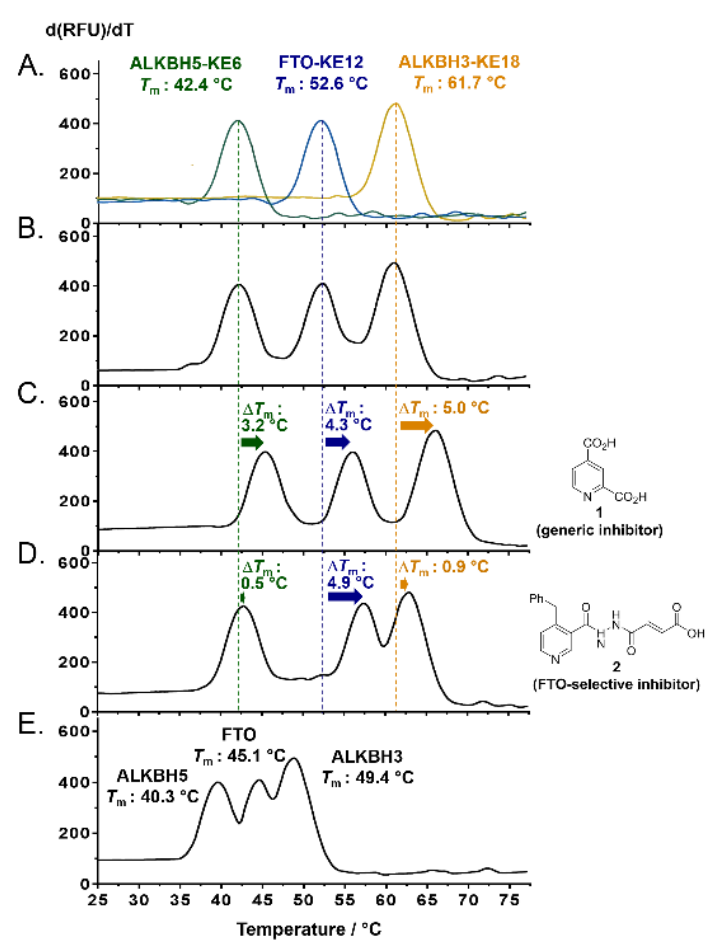

Figure 3. The thermal tags provide a basis for differential analysis of several proteins simultaneously. The DSF-based melting profiles of ALKBH5-KE6, FTOKE12 and $A L K B H 3-K E 18$, when analysed $(A)$ individually and $(B)$ as a mixture, revealed that mixing of fusion proteins do not affect their individual melting behaviour. Ligand binding experiments with $(C)$ 'generic' inhibitor $1(100 \mu \mathrm{M})^{[57]}$ and (D) FTO-selective inhibitor $2(100 \mu \mathrm{M}){ }^{[53]}$ demonstrated the capability of DSF detection strategy to monitor several protein-ligand interactions in a single DSF screen. (E) DSF analysis of a mixture of unmodified ALKBH5, FTO, and ALKBH3 produced an overlapping melting profile, demonstrating the power of the thermal tag approach in discriminating structurally-similar subfamily members.

of zwitterionic tags on protein activity could be reduced through the use of relatively short $6-18$ mer peptide sequences. Moreover the apparent lack of influence on protein conformations and catalytic activities further suggests that both KE and RD tags likely exist as separate entities, structurally and functionally independent from the proteins to which they were attached.

Taken together, our results clearly demonstrated that both KEand RD-tags are highly versatile thermal tags that are able to exclusively fine-tune the thermal stability and melting temperature of AlkB proteins, without compromising their structural conformation and catalytic activity. To our knowledge, this is the first report demonstrating that zwitterionic peptides could provide a general strategy for bioengineering proteins with the desired melting characteristics.

The thermal tags provide a basis for recognition and analysis of multiple proteins in a mixture

To establish whether thermal tag-induced $T_{\mathrm{m}}$ change could facilitate the discrimination of different fusion proteins in the same mixture, we performed one-pot DSF analysis of a mixture of ALKBH5-KE6 $\left(T_{\mathrm{m}}=42.4{ }^{\circ} \mathrm{C}\right)$, FTO-KE12 $\left(T_{\mathrm{m}}=52.6{ }^{\circ} \mathrm{C}\right)$ and ALKBH3-KE18 $\left(T_{\mathrm{m}}=61.7^{\circ} \mathrm{C}\right)$; these proteins were selected as they have reasonably large difference in $T_{\mathrm{m}}$ between them. We appreciate that most proteins undergo aggregation during thermal unfolding, we were therefore concerned that protein aggregates derived from the melting of one protein might interfere with the melting behaviour of other proteins within the same mixture. Nevertheless, in our multi-protein DSF analysis, three distinct denaturation peaks were observed which resembled the melting profile of ALKBH5-KE6 superimposed with that of FTO-KE12 and ALKBH3-KE18, suggesting that mixing of fusion proteins do not significantly alter their individual melting characteristics (Figures $3 A, B$ ). Consistent with our detection strategy, there was also a marked separation of individual melting peaks $\left(\Delta T_{\mathrm{m}}>9^{\circ} \mathrm{C}\right)$, which enables any ligand-induced $T_{\mathrm{m}}$ shift to be clearly detected without merging of peaks, as demonstrated by ligand binding experiments with 2,4-pyridine dicarboxylic acid 1 (a known 'generic' inhibitor of AlkB subfamilies), ${ }^{[57]}$ and FTO-selective inhibitor 2 (PubChem ID : 126970771; Figure 3C,D). ${ }^{[53]}$ By comparison, DSF analysis of a mixture of untagged ALKBH5, FTO, and ALKBH3 produced an overlapping melting profile which is difficult to deconvolute (Figure $3 \mathrm{E}$ ). Thus the combined use of thermal tags with DSF enables the simultaneous analysis of different fusion proteins in a mixture, even structurally-similar subfamily members which is otherwise challenging to differentiate.

Notably, in our multi-protein DSF strategy, different thermal tags were applied to different AlkB subfamilies. Hence one possible issue is that fusion proteins bearing longer, more stabilising tags might be less sensitive to further stabilisation by ligands than those with shorter tags. However, titration of each fusion protein against increasing concentrations of 1 revealed that proteins with KE18 tag exhibited similar concentration-dependent increase in $T_{\mathrm{m}}$ as those with KE12 and KE6 tags (Figure S3). Thus the length of thermal tag used does not significantly impact the magnitude of ligand-induced $T_{\mathrm{m}}$ shift.

\section{Analysis of self-assembly dynamics with multi-protein DSF detection strategy}

On the basis of these promising results, we next investigated whether the developed detection strategy could be used in combination with DCC to achieve multi-protein targeting. As our model dynamic reaction, we chose the reversible acyl hydrazone reaction between scaffold ligand 3 and aldehydes (Figure 4A). The acyl hydrazone exchange is one of the most well-established reversible reactions, first introduced by the Sanders group ${ }^{[58]}$ and subsequently by others ${ }^{[18,59,60]}$ for the preparation of dynamic library. By design, scaffold $\mathbf{3}$ contains a hydrazide moiety that is free to participate in acyl hydrazone exchange with a set of aldehydes. It also contains a pyridyl function which, based on modelling analysis, is expected to bind to the AlkB subfamilies via chelation with the active site $\mathrm{Fe}(\mathrm{II})$. Another notable feature is that 3 exhibits similar binding affinity for ALKBH5-KE6 $\left(K_{\mathrm{D}, \mathrm{app}}=37.9\right.$ $\left.\pm 4 \mu \mathrm{M} ; \Delta T_{\mathrm{m}}=1.5^{\circ} \mathrm{C}\right)$, FTO-KE12 $\left(K_{\mathrm{D}, \mathrm{app}}=40.4 \pm 4 \mu \mathrm{M} ; \Delta T_{\mathrm{m}}=\right.$ $\left.0.7{ }^{\circ} \mathrm{C}\right)$ and ALKBH3-KE18 $\left(K_{\mathrm{D} \text {,app }}=31.0 \pm 3 \mu \mathrm{M} ; \Delta T_{\mathrm{m}}=1.4^{\circ} \mathrm{C}\right)$, thus it does not inherently favour any particular protein template (Figures S6-S8). The weak potency of $\mathbf{3}$ against all three proteins also enables the effect of hydrazone substitution to be monitored. 
A. Acyl hydrazone exchange

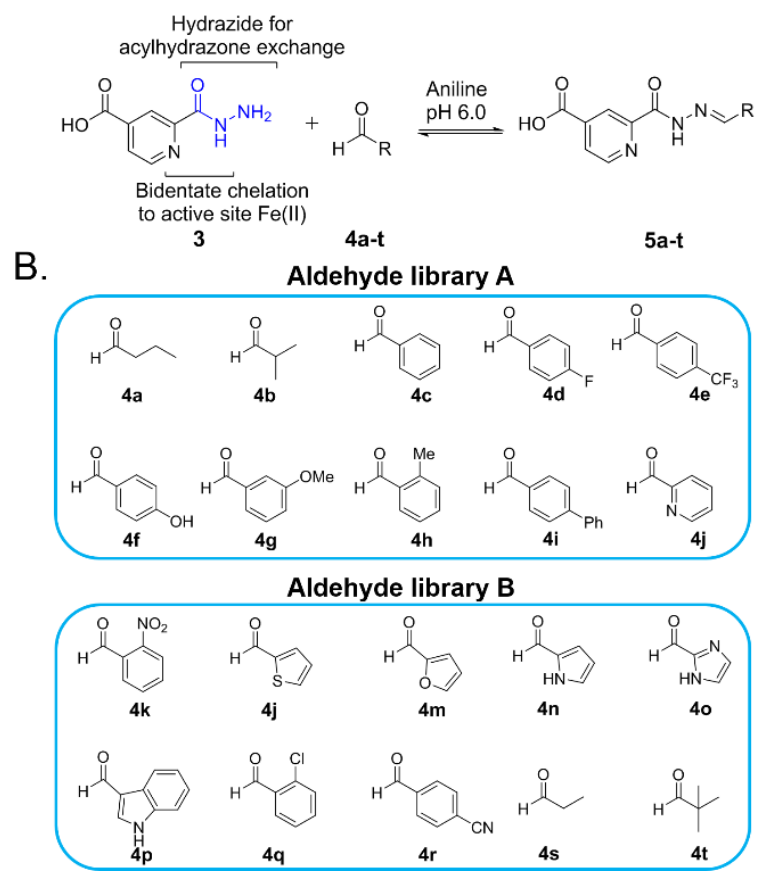

Figure 4. Formation of acyl hydrazone dynamic library. (A) The scaffold ligand 3 contains a pyridyl function which is expected to bind to the AlkB subfamilies via chelation with the active site Fe(II), leaving the hydrazide side chain (blue) free to participate in acyl hydrazone exchange with aldehydes. To facilitate rapid acyl hydrazone exchange, the reaction was performed under slightly acidic condition $(\mathrm{pH} 6.0)$ in the presence of a nucleophilic catalyst aniline. ${ }^{[88]}(\mathrm{B})$ Structures of aldehydes used in this study.

In a typical multi-protein DCC system, the dynamic library was set up by mixing all three fusion proteins i.e. ALKBH5-KE6 $(2 \mu \mathrm{M})$, FTO-KE12 $(2 \mu \mathrm{M})$, ALKBH3-KE18 $(2 \mu \mathrm{M})$ with $\mathrm{MnCl}_{2}(50 \mu \mathrm{M}$; substitute for $\mathrm{Fe}(\mathrm{II}))$ and scaffold $3(40 \mu \mathrm{M})$, in the presence of ten aldehydes 4a-j, each aldehyde at $20 \mu \mathrm{M}$ (library A; Figure 4B). The use of a fairly low concentration of aldehydes (10-fold relative to individual protein concentration) was a deliberate strategy to only detect high affinity ligand. To facilitate rapid acyl hydrazone exchange, the reaction was performed under slightly acidic condition ( $\mathrm{pH} 6.0)$ in the presence of aniline $(5 \mathrm{mM})$, which serves as a nucleophilic catalyst. ${ }^{[18,61]}$ The dynamic exchange was monitored using both DSF and HPLC analyses (Figure 5 and S4).

Initially at $t_{0}$, the reaction mixture consisted predominantly of scaffold 3 and free aldehydes, with no apparent hydrazone adduct formation or $T_{\mathrm{m}}$ shift (Figure 5A,E). After a 1-hour incubation, a distinct $T_{\mathrm{m}}$ shift could be detected for FTO-KE12 $\left(\Delta T_{\mathrm{m}}=3.9^{\circ} \mathrm{C}\right.$; Figure $5 \mathrm{~B}$ ). This was likely induced by specific binding of $\mathbf{5 e}$ to FTO-KE12, as supported by the concomitant amplification of hydrazone adduct $\mathbf{5 e}$ in HPLC analysis (Figure 5F). As the reaction progressed, amplification of a second hydrazone adduct $5 \mathrm{~h}$ became apparent at $2 \mathrm{~h}$, which resulted in a slight $T_{\mathrm{m}}$ shift for ALKBH3-KE18 $\left(\Delta T_{\mathrm{m}}=2.7^{\circ} \mathrm{C}\right.$; Figure $\left.5 \mathrm{C}, \mathrm{G}\right)$. The $T_{\mathrm{mS}}$ of FTOKE12 and ALKBH3-KE18 increased steadily over time, giving $T_{\mathrm{m}}$ shifts of $6.1^{\circ} \mathrm{C}$ and $4.0^{\circ} \mathrm{C}$, respectively after $5 \mathrm{~h}$ incubation (Figure $5 \mathrm{D}, \mathrm{H})$. This was accompanied with an increase in amplification of $\mathbf{5 e}$ and $\mathbf{5 h}$ to $\sim 35 \%$ and $\sim 32 \%$ of total adduct concentration, respectively (Figure $5 \mathrm{I}$ ). Detailed analysis revealed an excellent linear relationship between $T_{\mathrm{m}}$ shift and adduct concentration, hence the magnitude of $T_{\mathrm{m}}$ shift provides a direct indication of the extent of adducts amplification (Figure $5 \mathrm{~J}$ ). Although some degree of fluorescence quenching occurred in the presence of the library components, the observed $T_{\mathrm{m}}$ shifts were highly reproducible (standard deviations $<1^{\circ} \mathrm{C}$ ). To determine if heating of the DCL during DSF analysis could affect DCL equilibration, we performed HPLC analysis of the DCL at various temperatures, ranging from $37{ }^{\circ} \mathrm{C}$ to $70{ }^{\circ} \mathrm{C}$ (Figure S5). The results revealed no significant change in $\mathrm{DCL}$ equilibration even when heated to a temperature of $70^{\circ} \mathrm{C}$, although increasing $\mathrm{DCL}$ temperature did cause a decrease in retention time, which led to the merging of some adduct peaks.

The identity of the preferentially binding hydrazones was subsequently confirmed by separate DSF experiments in which the ten aldehydes $\mathbf{4 a - j}$ were individually mixed with $\mathbf{3}$, and then analysed for $T_{\mathrm{m}}$ shift with the fusion proteins. This established adducts $\mathbf{5 e}$ and $\mathbf{5 h}$ to be the specific binder for FTO-KE12 and ALKBH3-KE18, respectively. Consistent with DCC result, no $T_{\mathrm{m}}$ shifts were observed for ALKBH5-KE6 for all combinations of 3 and aldehydes.

The combined use of multi-protein DSF detection with DCC enables multi-protein targeting

We appreciate that, to date, DSF analysis has primarily been used to study the binding of stable ligands to protein. Therefore $T_{\mathrm{m}}$ shift data derived from labile and interchanging protein-ligand complexes may not reflect actual ligand binding affinity. To verify our multi-protein DCC result, we determined the binding affinities of the identified hits $\mathbf{5 e}$ and $\mathbf{5} \mathbf{h}$ using NMR-based water relaxation assay. ${ }^{[14,62]}$ In this method, the apparent binding constants $\left(K_{\mathrm{D}, \text { app }}\right)$ were determined by monitoring the bulk water relaxation rate, which decreased when water access to paramagnetic $\mathrm{Mn}$ (II) in the active site was hindered through binding of ligands to the metal.

Our NMR assays support results from DCC, where a substantial increase in the binding affinity of 3 for FTO-KE12 $\left(K_{\mathrm{D} \text {,app }}=40.4\right.$ $\pm 4 \mu \mathrm{M}$ ) was observed only in the presence of aldehyde $4 \mathrm{e}$ $\left(K_{\mathrm{D}, \text { app }}(\mathbf{5 e})=0.46 \pm 0.1 \mu \mathrm{M}\right.$; Figure $\left.5 \mathrm{~K}\right)$; the presence of other aldehydes has negligible effect on the binding affinity of 3 (Figure S6). As anticipated, the affinity of 3 for ALKBH3-KE18 $\left(K_{\mathrm{D}, \mathrm{app}}=31.0 \pm 3 \mu \mathrm{M}\right)$ was improved only when combined with aldehyde $4 \mathbf{h}\left(K_{\mathrm{D}, \mathrm{app}}(\mathbf{5 h})=1.0 \pm 0.2 \mu \mathrm{M}\right.$; Figure $\left.5 \mathrm{~L}\right)$, and not with other aldehydes (Figure S7). Finally, the binding of 3 to ALKBH5KE6 $\left(K_{\mathrm{D}, \text { app }}=37.9 \pm 4 \mu \mathrm{M}\right)$ was also not significantly altered by any of the aldehydes investigated (Figure S8). Thus there is qualitative agreement between $T_{\mathrm{m}}$ shift data derived from DCC screen and ligand binding affinities. Our results therefore clearly demonstrated that DSF technique can indeed be used to monitor and analyse self-assembly dynamics in multi-component DCC system.

Importantly, the successful identification of adducts $\mathbf{5 e}$ and $\mathbf{5 h}$ validates the capability of our multi-protein DCC approach to 
identify highly selective ligands against several targets simultaneously. Notably, adducts $\mathbf{5 e}$ differ from $\mathbf{5 h}$ by only a single isosteric replacement of para- $\mathrm{CF}_{3}$ with ortho-Me group, thus this approach has the sensitivity to detect subtle active site selectivity between structurally-related subfamily members.

Comparing the effects of single-templating and multitemplating on ligand selection

We next compared the impact of single-templating and multi-templating on ligand selection. We performed another set of DCC experiments in which the dynamic library was constituted by mixing scaffold $\mathbf{3}$ and aldehydes $\mathbf{4 k - t}$ (library B, Figure 4B). When the dynamic library was screened against each protein individually (single-templating), we observed substantial binding of adduct 5k to ALKBH5-KE6 $\left(\Delta T_{\mathrm{m}}=4.8{ }^{\circ} \mathrm{C}\right)$, FTO-KE12 $\left(\Delta T_{\mathrm{m}}\right.$ $\left.=3.0{ }^{\circ} \mathrm{C}\right)$, and ALKBH3-KE18 $\left(\Delta T_{\mathrm{m}}=3.4{ }^{\circ} \mathrm{C}\right.$; Figure S9A-C). However, when the same dynamic library was screened against all three proteins concurrently (multiple-templating), the binding of $5 \mathbf{k}$ to each protein was reduced to near zero $\left(\Delta T_{\mathrm{mS}} 0.1-0.3^{\circ} \mathrm{C}\right.$; Figure S9D). DSF-based titration experiments further revealed that when all three proteins were present, a considerably higher concentration of $\mathbf{5 k}(\sim 31 \mu \mathrm{M})$ was required to produce a significant $T_{\mathrm{m}}$ shift of $1.0^{\circ} \mathrm{C}$ in FTO-KE12, compared to just $\sim 3 \mu \mathrm{M}$ when only
FTO-KE12 was present (Figure S10). In sharp contrast, the binding of selective ligands to their protein targets was not affected by the presence or absence of other proteins. For instance, the binding of $5 \mathbf{e}(10 \mu \mathrm{M})$ to FTO-KE12 elicits a similar $T_{\mathrm{m}}$ shift of $\sim 5^{\circ} \mathrm{C}$ whether in the presence of a single or multiple protein templates (Figure S9E,F). Importantly, in dynamic library containing both selective and non-selective adducts $\mathbf{5 e}$ and $\mathbf{5 k}$ (set up by adding aldehyde $20 \mu \mathrm{M} \mathrm{4e}$ to the above dynamic library), only the specific binding of $\mathbf{5 e}$ to FTO-KE12 could be detected (Figure S9G). Taken together, the results suggest that the extent of $T_{\mathrm{m}}$ shifts in multi-templating DCC experiment is primarily dependent on the affinity of the ligands for the target proteins. Presumably, strong binders, such as $\mathbf{5 e}$, dominates the DCL equilibrium at the expense of weak binders, such as $\mathbf{5 k}$, whilst weak binders dominate the DCL equilibrium over the nonbinders.

\section{Multi-protein DCC led to the identification of subfamily- selective probes for FTO and ALKBH3}

To establish whether the hits identified from our multi-protein DCC screen were in fact active inhibitors of AlkB demethylases, we synthesised stable analogues of $\mathbf{5 c}, \mathbf{5 e}, \mathbf{5 h}$ and $\mathbf{5 k}$, wherein the relatively labile acyl hydrazone moiety was replaced with a stable

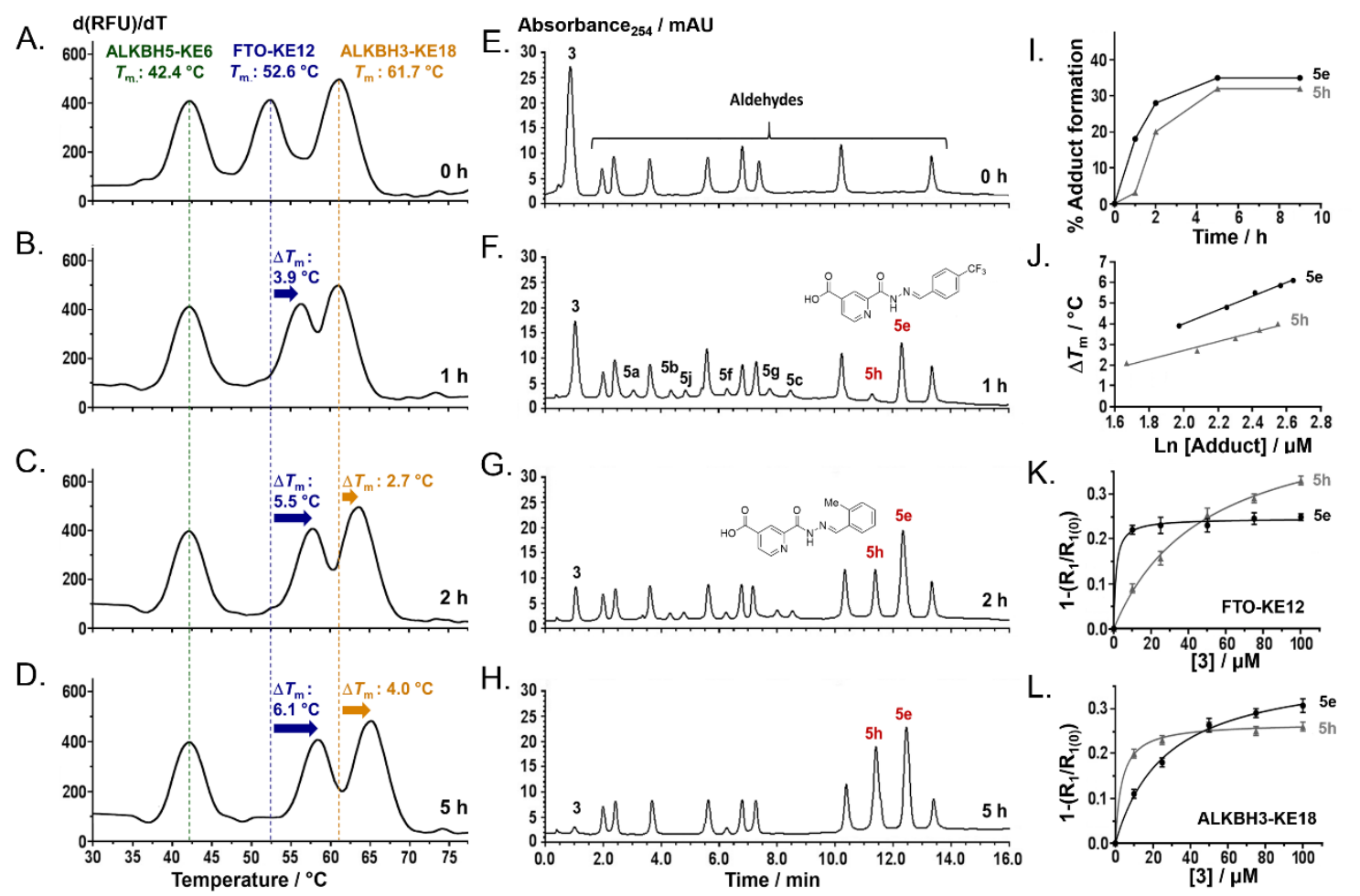

Figure 5. The multi-protein DSF detection strategy enables the analysis of self-assembly dynamics. The dynamic library was constituted by mixing ALKBH5-KE6 $(2 \mu \mathrm{M})$, FTO-KE12 $(2 \mu \mathrm{M})$, ALKBH3-KE18 $(2 \mu \mathrm{M})$, scaffold ligand $3(40 \mu \mathrm{M})$, aldehydes $4 a-\mathrm{j}$ (library A, each aldehyde at $20 \mu \mathrm{M})$, MnCl $2(50 \mu \mathrm{M})$ and aniline $(5 \mathrm{mM})$ in HEPES buffer (50 mM, pH 6.0). (A-D) DSF melting analyses showed time-dependent increase in Tm shift for FTO-KE12 and ALKBH3-KE18, suggesting the simultaneous assembly of hydrazone adducts capable of substantial binding to FTO-KE12 and ALKBH3-KE18. (E-H) HPLC analyses of the dynamic library revealed concomitant amplification of adducts $\mathbf{5 e}$ and $\mathbf{5 h}$, at the expense of other hydrazone adducts. The peaks were assigned based on retention times of pure aldehydes and adducts. (I) The concentrations of the adducts were determined based on their respective HPLC peak areas, using calibration plots obtained from pure adducts. The percentages of adduct formation were calculated relative to the starting concentration of scaffold ligand $3(40 \mu \mathrm{M})$. ( $\mathrm{J}$ ) There is an excellent linear relationship between $T_{m}$ shift and In (adduct concentration), thus the magnitude of $T_{m}$ shift provides a direct indication of the extent of adducts amplification. (K-L) NMR-based water relaxation assay confirms adducts $\mathbf{5 e}$ and $\mathbf{5 h}$ to be the specific binders for FTO-KE12 and ALKBH3-KE18, respectively. Error bars represent SD of three replicates. 


$$
\begin{array}{rlrl}
20 \mathrm{R} & =\mathrm{H} & \\
21 \mathrm{R} & =3-\mathrm{CF}_{3} & 6 \mathrm{R}=\mathrm{H}
\end{array}
$$

Scheme 1. Synthesis of stable sulphonamide analogues $\mathbf{6 - 1 5}$. ${ }^{a}$ Compounds $\mathbf{6 - 9}$ are stable analogues of identified hydrazone hits $\mathbf{5 c}, \mathbf{5 e}, \mathbf{5 h}$ and $\mathbf{5 k}$, respectively, wherein the relatively labile acyl hydrazone moiety was replaced with a stable sulphonamide moiety. Reagents and conditions: (i) substituted benzenesulfonamides, $\mathrm{Et}_{3} \mathrm{~N}, 1$-hydroxybenzotriazole hydrate, 1-ethyl-3-(3-dimethylaminopropyl)carbodiimide hydrochloride, $\mathrm{CH}_{2} \mathrm{Cl}_{2}, 25^{\circ} \mathrm{C}$; (ii) $\mathrm{LiOH}$, tetrahydrofuran-water $4: 1,25^{\circ} \mathrm{C}$. See Experimental Section and Supporting Information for full synthesis, characterisation and NMR spectra of compounds.

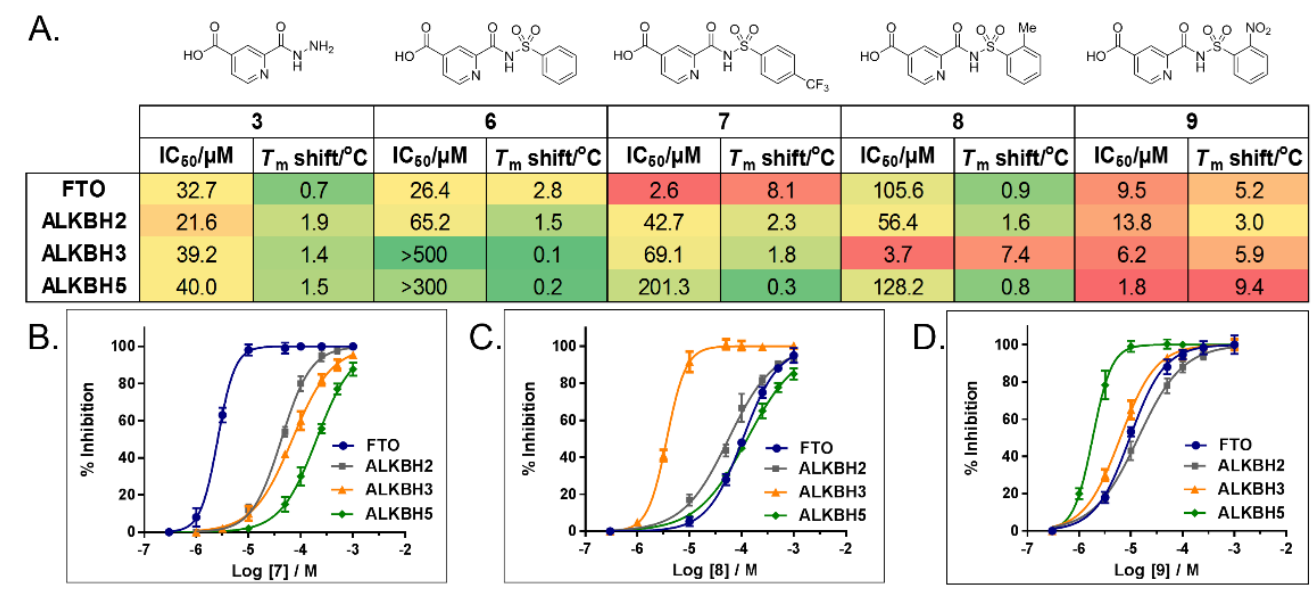

Figure 6. Activity profiling of the sulphonamide analogues against representatives AlkB subfamilies. (A) Consistent with multi-protein DCC results, 7 demonstrates distinct selectivity for FTO, with substantially reduced inhibition and $T_{m}$ shift against other AlkB subfamilies, whilst 8 exhibited $>100$-fold selectivity for ALKBH3 over FTO and ALKBH5. 7 and 8 also discriminates against other human 2OG oxygenases, as demonstrated by their poor inhibitory activities against JMJD2A (IC 50 S $>100 \mu \mathrm{M}$ ). The reported values are average of three replicates. Enzyme inhibition curves of (B) 7, (C) 8, and (D) 9, as determined using HPLC-based assay. Error bars represent SD of three replicates. For enzyme inhibition curves of compounds 3 and $\mathbf{6}$, see Figure S11.

sulphonamide moiety (Scheme 1). It should be emphasised that the key result of any DCC experiment is the information about the most effective structural combinations of building blocks. Hence labile groups like hydrazones are often replaced to form stable ligands. ${ }^{[63]}$

The resulting stable analogues, 6-9, were evaluated for activity against a panel of untagged AlkB subfamilies using both HPLCbased demethylase assay and $T_{\mathrm{m}}$ shift assay (for assay conditions, see Supporting Information).

As shown in Figure 6, the $T_{\mathrm{m}}$ shift and inhibition data are in close agreement with multi-protein DCC results. In particular, compounds 7 (analogue of 5e) and 8 (analogue of $5 \mathrm{~h}$ ) were indeed potent inhibitors of FTO $\left(\mathrm{IC}_{50}=2.6 \mu \mathrm{M}, \Delta T_{\mathrm{m}}=8.1^{\circ} \mathrm{C}\right)$ and ALKBH3 $\left(\mathrm{IC}_{50}=3.7 \mu \mathrm{M}, \Delta T_{\mathrm{m}}=7.4^{\circ} \mathrm{C}\right)$, respectively, with $\mathrm{IC}_{50}$ values in low micromolar range, which represents more than 10 -fold improvement in activity compared with scaffold ligand $\mathbf{3}$. Notably, compound $\mathbf{9}$ (analogue of $\mathbf{5 k}$ ), which was identified by the single-templated DCC, was also found to be a relatively potent, non-selective inhibitor, and control compound 6 (analogue of $5 \mathrm{c}$ ) a poor inhibitor against all AlkB enzymes investigated $\left(\mathrm{IC}_{50}>25 \mu \mathrm{M}\right)$.

The selectivity profiles of compounds $\mathbf{7}$ and $\mathbf{8}$ are also strikingly consistent with multi-protein DCC results (Figure 6). In particular, we observed remarkable selectivity of 7 for FTO, with substantially reduced inhibition and $T_{\mathrm{m}}$ shift against ALKBH3 $\left(\mathrm{IC}_{50}=69.1 \mu \mathrm{M}, \Delta T_{\mathrm{m}}=1.8^{\circ} \mathrm{C}\right)$ and ALKBH5 $\left(\mathrm{IC}_{50}=201.3 \mu \mathrm{M}\right.$, $\Delta T_{\mathrm{m}}=0.3{ }^{\circ} \mathrm{C}$ ), whilst 8 exhibited $>100$-fold greater activity for ALKBH3 over FTO $\left(\mathrm{IC}_{50}=105.6 \mu \mathrm{M}, \Delta T_{\mathrm{m}}=0.9^{\circ} \mathrm{C}\right)$ and ALKBH5 $\left(\mathrm{IC}_{50}=128.2 \mu \mathrm{M}, \Delta T_{\mathrm{m}}=0.8^{\circ} \mathrm{C}\right)$. Further profiling studies revealed that 7 and 8 also discriminate against other human $20 \mathrm{G}$ oxygenases, as demonstrated by their poor inhibitory activities against ALKBH2 $\left(\mathrm{IC}_{50} \mathrm{~S}>40 \mu \mathrm{M}\right)$ and JMJD2A $\left(\mathrm{IC}_{50} \mathrm{~S}>100 \mu \mathrm{M}\right.$; a histone demethylase critically involved in chromatin remodelling) ${ }^{[64]}$ Our results therefore validate the multi-protein DCC screen as a reliable method for the simultaneous identification of subfamily-selective probes.

To rationalise the selectivity of $\mathbf{7}$ and $\mathbf{8}$, a series of mono-, di-, and tri-methyl substituted analogues 10-15 was prepared and evaluated for activities against the AlkB subfamilies. The assay 


\begin{tabular}{|c|c|c|c|c|c|c|c|c|c|c|c|c|}
\hline & \multicolumn{2}{|c|}{8} & \multicolumn{2}{|c|}{10} & \multicolumn{2}{|c|}{11} & \multicolumn{2}{|c|}{12} & \multicolumn{2}{|c|}{13} & \multicolumn{2}{|c|}{14} \\
\hline & $I C_{50} / \mu \mathrm{M}$ & $T_{\mathrm{m}}$ shift $/^{\circ} \mathrm{C}$ & $I C_{50} / \mu \mathrm{M}$ & $T_{\mathrm{m}}$ shift $/^{\circ} \mathrm{C}$ & $\mathrm{IC}_{50} / \mathrm{\mu M}$ & $T_{\mathrm{m}}$ shift $/{ }^{\circ} \mathrm{C}$ & $\mathrm{IC}_{50} / \mu \mathrm{M}$ & $T_{\mathrm{m}}$ shift $/^{\circ} \mathrm{C}$ & $\mathrm{IC}_{50} / \mathrm{MM}$ & $T_{\mathrm{m}}$ shift $^{\circ} \mathrm{C}$ & $\mathrm{IC}_{50} / \mathrm{\mu M}$ & $T_{\mathrm{m}}$ shift $/^{\circ} \mathrm{C}$ \\
\hline FTO & 105.6 & 0.9 & 5.8 & 5.2 & 4.6 & $\begin{array}{ll}6.7 \\
\end{array}$ & 4.0 & 6.9 & 7.9 & 4.6 & 5.2 & 6.3 \\
\hline ALKBH2 & 56.4 & 1.6 & 56.6 & 1.7 & 25.8 & 2.5 & 10.8 & 3.3 & 85.3 & 1.1 & 106.9 & 0.7 \\
\hline ALKBH3 & 3.7 & 7.4 & 11.4 & 3.0 & 23.3 & 2.8 & 25.1 & 2.7 & 41.3 & 2.5 & 21.2 & 2.5 \\
\hline ALKBH5 & 128.2 & 0.8 & $>300$ & 0.3 & 75.5 & 1.3 & $>300$ & 0.2 & 68.4 & 1.5 & $>300$ & 0.3 \\
\hline
\end{tabular}

\begin{tabular}{|c|c|c|c|c|}
\hline & \multicolumn{2}{|c|}{7} & \multicolumn{2}{|c|}{15} \\
\hline & $\mathrm{IC}_{50} / \mu \mathrm{M}$ & $T_{\mathrm{m}}$ shift $/{ }^{\circ} \mathrm{C}$ & $\mathrm{IC}_{50} / \mu \mathrm{M}$ & $T_{\mathrm{m}}$ shift $/^{\circ} \mathrm{C}$ \\
\hline FTO & 2.6 & 8.1 & 36.7 & 2.0 \\
\hline ALKBH2 & 42.7 & 2.3 & 46.2 & 1.8 \\
\hline ALKBH3 & 69.1 & 1.8 & 22.5 & 2.9 \\
\hline ALKBH5 & 201.3 & 0.3 & $>300$ & 0.1 \\
\hline
\end{tabular}

Figure 7. Selectivity studies of analogues of (A) ALKBH3-selective inhibitor 8, and (B) FTO-selective inhibitor 7. In all compounds investigated, the introduction of a methyl or trifluoromethyl substituent at the ortho-position favours ALKBH3 selectivity, whereas a translocation of these groups to the meta- or para-positions promotes FTO selectivity, as apparent from a comparison of the selectivity profile of 8 with 10 and $\mathbf{1 1}$, or that of 7 with 15 . Likewise, the addition of either a m-methyl or p-methyl group to 8 (i.e. 12-14) drives selectivity towards FTO. The reported values are average of three replicates.

result was summarised in Figure 7 . It suggests that the introduction of a methyl substituent at the ortho-position (i.e. 8) favours ALKBH3 selectivity, whereas shifting it to either the meta(i.e. 10) or para-positions (i.e. 11) drives selectivity towards FTO. This change in selectivity was particularly apparent when comparing the activity of 8 with that of analogues 12-14. In all cases, the addition of either a $m$-methyl or $p$-methyl group caused a substantial increase in selectivity towards FTO.

A similar trend was also observed for $\mathbf{7}$, whereby a translocation (i.e. 15) resulted in a 14-fold reduction in potency against FTO, coupled with an increase (3-fold) in potency towards ALKBH3 (Figure 7B). Notably, these substitution changes have very little or no effect on activities towards ALKBH2 and ALKBH5. The structural models of FTO-7 and ALKBH3-7 complexes built using the reported crystal structures of FTO (PDB ID 4CXW[53]) and ALKBH3 (PDB ID 2IUW ${ }^{[54]}$; Figure 8) reveal that compound 7 is able to coordinate with the active site $\mathrm{Fe}(\mathrm{II})$ in a bidentate manner and participate in hydrogen-bonding interactions with the side

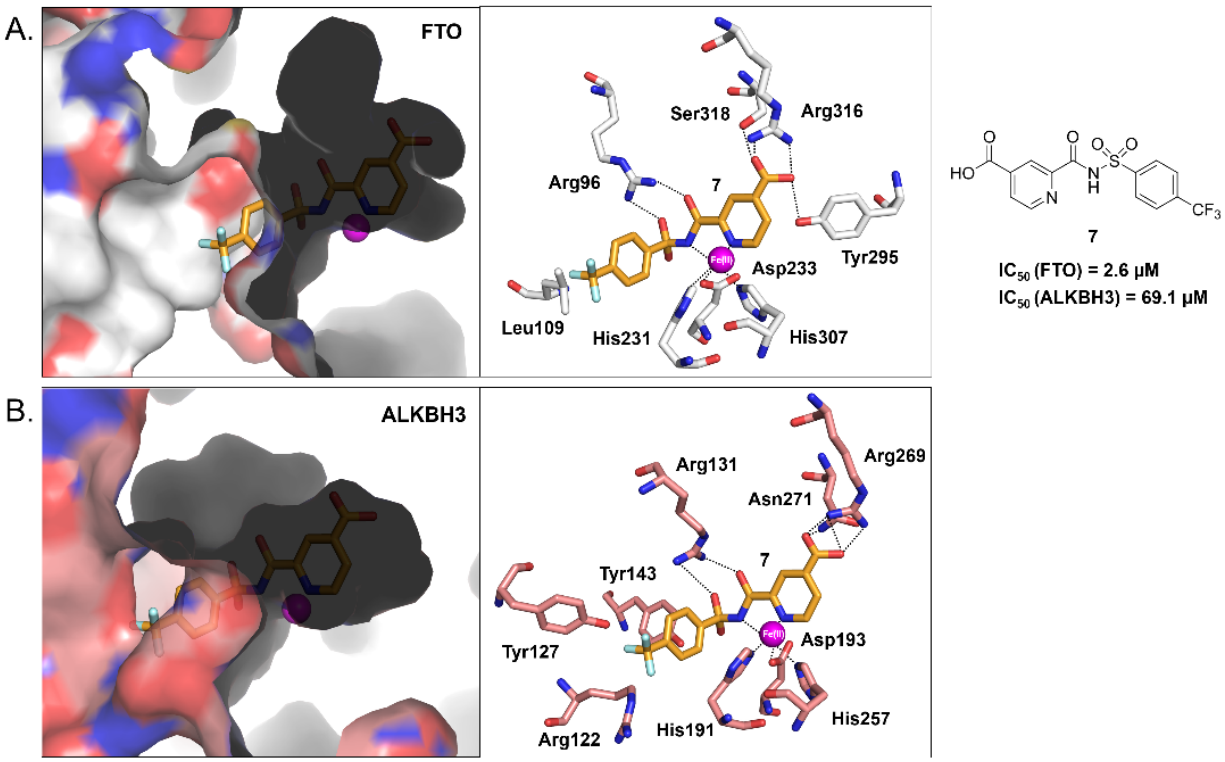

of its trifluoromethyl substituent from the para- to ortho-position chains of $\operatorname{Arg} 96(2.4 \AA$ and $2.5 \AA)$. The pyridyl carboxylate group is Figure 8. Rationalisation for the selectivity of $\mathbf{7}$ for FTO over ALKBH3. The structural models of the (A) FTO-7 complex, and (B) ALKBH3-7 complex built using reported crystal structures of FTO (white surface and white sticks; PDB ID 4CXW ${ }^{[53]}$ ) and ALKBH3 (salmon surface and salmon sticks; PDB ID 2IUW[54]). The right panels show the close-up views of interactions between $\mathbf{7}$ and active site residues in FTO and ALKBH3. Whereas $\mathbf{7}$ forms highly favourable interactions with FTO, it is unable to fit into the binding pocket of ALKBH3 due to steric clash between its 4-trifluoromethylphenyl group and the side chain of Tyr143. 
further stabilised through formation of salt bridges with both $N^{\omega}$ of $\operatorname{Arg} 319(2.5 \AA$ and $2.7 \AA)$, and hydrogen-bonds with the hydroxyl

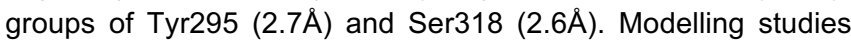
further suggest that 7 might not be able to fit into the binding pocket of $A L K B H 3$ due to potential steric clash between its 4-trifluoromethylphenyl group and the side chain of Tyr143. This may contribute to the poor activity of 7 against ALKBH3 (Figure $8 \mathrm{~B}$ ). However the proposed model is unable to account for the activity of compounds $\mathbf{8}$ and $\mathbf{1 5}$, since similar steric clash is also possible between these compounds and ALKBH3. Further crystallographic studies are needed to determine the exact structural basis for the selectivity of these inhibitors. Studies are also currently underway to determine the potency and selectivity of $\mathbf{7}$ and $\mathbf{8}$ in cells, which will provide insight on their usefulness as functional probes and, possibly, therapeutic leads.

\section{Conclusions}

Overall, we used a combination of protein engineering, spectroscopic, thermodynamic, kinetic, biochemical and thermal denaturation studies to investigate the effects of zwitterionic tags on protein structures and functions. Our results revealed that the incorporation of a single KE or RD peptide, as short as 6 to 18 residues in length, can trigger dramatic increase in thermal stability and melting temperature of the host proteins without disrupting their structural conformations and catalytic activities. We further showed that both KE and RD tags are highly versatile thermal tags and are generally applicable to a range of proteins, including AlkB subfamilies such as FTO, ALKBH3, and ALKBH5. To our knowledge, this is the first report showing that zwitterionic peptides can be used to exclusively fine-tune the melting temperature of proteins. Importantly, by exploiting thermal taginduced $T_{\mathrm{m}}$ change, we developed a novel DSF-based detection strategy which enables the analysis of several protein-ligand interactions simultaneously. The assay is remarkably sensitive and could effectively distinguish the binding of ligands to different proteins, including structurally-similar subfamily members, which is extremely challenging to achieve. Through the combine use of multi-protein DSF and DCC, we were able to achieve simultaneous discovery of highly selective probes against several target proteins. This was demonstrated by the identification of compounds 7 and $\mathbf{8}$, which not only exhibit exceptional selectivity for FTO $\left(\mathrm{IC}_{50}=2.6 \mu \mathrm{M}, \Delta T_{\mathrm{m}}=8.1^{\circ} \mathrm{C}\right)$ and ALKBH3 $\left(\mathrm{IC}_{50}=3.7 \mu \mathrm{M}\right.$, $\Delta T_{\mathrm{m}}=7.4^{\circ} \mathrm{C}$ ), respectively over other AlkB subfamilies, but also discriminate against structurally-related human $20 \mathrm{G}$ oxygenases, such as JMJD2A. Notably, to date, there is no report of subfamilyselective ALKBH3 inhibitor. In light of the biological and clinical significance of FTO and ALKBH3, we envisaged that the identified inhibitors would be of interest as functional probes and, possibly, therapeutic leads.

One limitation of this approach is that it is only applicable to proteins that are amenable to $T_{\mathrm{m}}$ modification by the thermal tags. Conceivably the use of a larger number of proteins will produce significant $T_{\mathrm{m}}$ signal overlap, and this limits the number of protein templates that can be analysed concurrently. Moreover, it is necessary to carry out separate experiments to determine the identity of the best binders. Nevertheless, the method is relatively simple, cheap and amenable to a high-throughput format. Moreover unlike current techniques, such as HPLC and NMR analyses, it detects ligands binding rather than amplification of the best binders, which greatly simplifies spectral analysis, thus potentially permits the use of larger, more complex dynamic library. Although this study focuses on the development of multiprotein DCC, the developed method is highly versatile and may, in principle, be adapted to a wide range of studies, such as parallel profiling of compound library, high-throughput mapping of protein substrate specificity, and the study of protein-protein/nucleic acid interactions. Thus, the approach outlined here shall be of general scientific interest.

To the best of our knowledge, this study represents not only the first example of multi-protein DCC, but also a new strategy for probing dynamic chemical system, which hopefully will further our understanding of protein-directed self-assembly, and inspire new applications for DCC-based approaches.

\section{Experimental Section}

\section{General procedures for compound synthesis}

Starting materials, reagents, and solvents were obtained from commercial sources and used as received. Progress of the reactions were monitored by thin layer chromatography, which was performed on precoated aluminum-backed plates (Merck, silica 60 F254). Purification of intermediates and final products was carried out using flash column chromatography conducted on silica gel (230-400 mesh). Melting points were determined using a Gallenkamp melting point apparatus. Infrared spectra were recorded on a PerkinElmer Spectrum 100 FT-IR spectrometer using neat compound. ${ }^{1} \mathrm{H}$ and ${ }^{13} \mathrm{C}$ NMR spectra were recorded using TMS as the internal standard with a Bruker Advance 400 Ultrashield NMR spectrometer at $400 \mathrm{MHz}$ and $100 \mathrm{MHz}$, respectively. Chemical shifts $(\delta)$ were reported in ppm downfield from the internal standard. The signals were quoted as $s$ (singlet), $d$ (doublet), t (triplet), $m$ (multiplet), br (broad). Coupling constants $J$ were given in $\mathrm{Hz}( \pm 0.5 \mathrm{~Hz})$. ESI-MS spectra were recorded on a Shimadzu LC-MS2020 mass spectrometer. High resolution mass spectra (HRMS) were recorded using Bruker MicroTOF-QII mass spectrometer. The purity of synthesised compounds was confirmed to be higher than $95 \%$ using analytical reversephase HPLC (Ultimate 3000). Compound 1 was commercially available and used without any further purification. Compound $\mathbf{2}$ was synthesised as previously reported. ${ }^{[53]}$ Synthesis and characterisation of selected compounds 7, 8, 17, 21, 22 are described below. For synthesis of other compounds investigated in this study, see Supporting Information.

4-(Methoxycarbonyl)picolinic acid (17). To a solution of dimethyl pyridine-2,4-dicarboxylate $16(1.4 \mathrm{~g}, 7.3 \mathrm{mmol})$ in methanol $(20 \mathrm{~mL})$, $1.2 \mathrm{~mL}$ of aqueous sodium hydroxide $(6 \mathrm{M})$ solution was added. The mixture was then stirred at room temperature for $10 \mathrm{~h}$, after which the solvent was evaporated in vacuo. The resulting residue was washed with ethyl acetate $(20 \mathrm{~mL})$, then dissolved in water $(40 \mathrm{~mL})$ and the aqueous solution acidified to $\mathrm{pH} 2$ with conc. $\mathrm{HCl}$ at $0{ }^{\circ} \mathrm{C}$. The mixture was then filtered to give 17 (368 mg, 28\%) as a white solid. m.p. $230-231{ }^{\circ} \mathrm{C} ;{ }^{1} \mathrm{H}$ NMR (400 MHz, DMSO- $\left.d_{6}\right): \delta=3.92\left(\mathrm{~s}, 3 \mathrm{H} ; \mathrm{CO}_{2} \mathrm{CH}_{3}\right), 8.05$ (d, $J=3.6 \mathrm{~Hz}$, $1 \mathrm{H}), 8.38(\mathrm{~s}, 1 \mathrm{H}), 8.91(\mathrm{~d}, J=4.4 \mathrm{~Hz}, 1 \mathrm{H}), 13.95\left(\mathrm{~s}, 1 \mathrm{H} ; \mathrm{CO}_{2} \mathrm{H}\right) ;{ }^{13} \mathrm{C}$ NMR $\left(100 \mathrm{MHz}, \mathrm{DMSO}-d_{6}\right): \delta=52.5\left(\mathrm{CO}_{2} \mathrm{CH}_{3}\right), 123.4,126.0,139.4,148.4$, 
150.9, $164.5\left(\mathrm{CO}_{2} \mathrm{CH}_{3}\right), 165.2\left(\mathrm{CO}_{2} \mathrm{H}\right) ; \mathrm{IR}$ (neat) $\mathrm{u} / \mathrm{cm}^{-1}=1707$ (CO); MS (ESI) $\mathrm{m} / \mathrm{z}$ : calcd. for $\left.\mathrm{C}_{8} \mathrm{H}_{6} \mathrm{NO}_{4}[\mathrm{M}-\mathrm{H}]\right]^{-}:$: 180.0. Found 180.3 .

\begin{abstract}
Methyl
2-(((4-(trifluoromethyl)phenyl)sulfonyl)carbamoyl)

isonicotinate (21). To a suspension of 4-(methoxycarbonyl)picolinic acid $17(154 \mathrm{mg}, 0.8 \mathrm{mmol})$ in dichloromethane $(3 \mathrm{~mL})$, triethylamine $(301 \mathrm{mg}$, $2.9 \mathrm{mmol})$, 1-hydroxybenzotriazole hydrate $(172 \mathrm{mg}, 1.2 \mathrm{mmol}), 1-$ (3-dimethylaminopropyl)-3-ethylcarbodiimide hydrochloride (245 $\mathrm{mg}$, $1.2 \mathrm{mmol}$ ) were added sequentially at room temperature. The reaction was stirred at room temperature for 30 minutes. Then 4-(trifluoromethyl)benzenesulfonamide ( $230 \mathrm{mg}, 1 \mathrm{mmol}$ ) was added. The reaction mixture was stirred at room temperature for 3 days. The reaction mixture was then diluted with dichloromethane, and washed by citric acid aqueous solution $(10 \%)$. The organic layer was neutralized by aqueous saturated $\mathrm{NaHCO}_{3}$ solution and dried over anhydrous $\mathrm{Na}_{2} \mathrm{SO}_{4}$. Then the solvent was removed in vacuo and the residue was purified by flash column chromatography (dichloromethane / methanol 10 : 1). The fractions collected were further purified by triturating with $n$-hexaneisopropanol and the precipitate was separated by filtration to give $\mathbf{2 1}$ as a white solid $(268 \mathrm{mg}, 81 \%) . R_{\mathrm{f}}=0.60$ (dichloromethane/methanol $4: 1$ ); m.p. $230-231{ }^{\circ} \mathrm{C} ;{ }^{1} \mathrm{H} \mathrm{NMR}(400 \mathrm{MHz}$, DMSO-d $)$ : $\delta=3.89\left(\mathrm{~s}, 3 \mathrm{H} ; \mathrm{CO}_{2} \mathrm{CH}_{3}\right)$ $7.79(\mathrm{~m}, 2 \mathrm{H}), 7.86(\mathrm{~m}, 2 \mathrm{H}), 8.02(\mathrm{~m}, 1 \mathrm{H}), 8.44(\mathrm{~s}, 1 \mathrm{H}), 8.71(\mathrm{~m}, 1 \mathrm{H}) ;{ }^{13} \mathrm{C}$ NMR $\left(100 \mathrm{MHz}\right.$, DMSO- $\left.d_{6}\right): \delta=52.3\left(\mathrm{CO}_{2} \mathrm{CH}_{3}\right), 123.4,123.9$ (q, ${ }^{1} \mathrm{JC}-\mathrm{F}$ $=270.8 \mathrm{~Hz}), 124.8\left(\mathrm{q},{ }^{3} \mathrm{~J} \mathrm{C}-\mathrm{F}=3.7 \mathrm{~Hz}\right), 125.5,127.8,133.1\left(\mathrm{q},{ }^{2} \mathrm{~J} \mathrm{C}-\mathrm{F}=31.7\right.$ $\mathrm{Hz}), 147.3,147.5,149.4,150.0,165.1(\mathrm{CONH}), 167.0\left(\mathrm{CO}_{2} \mathrm{CH}_{3}\right) ;{ }^{19} \mathrm{~F} \mathrm{NMR}$ (376.3 MHz, DMSO-d $d_{6}$ ): $\delta=61.20$; IR (neat) $u / \mathrm{cm}^{-1}=1170$ (SO), 1263 (CF), 1353, 1730 (CO); MS (ESI) $\mathrm{m} / \mathrm{z}$ : calcd. for $\mathrm{C}_{15} \mathrm{H}_{10} \mathrm{~F}_{3} \mathrm{~N}_{2} \mathrm{O}_{5} \mathrm{~S}[\mathrm{M}-\mathrm{H}]$ : 387.0. Found 387.1
\end{abstract}

2-(((4-(Trifluoromethyl)phenyl)sulfonyl)carbamoyl)isonicotinic acid (7). To a solution of methyl 2-(((4-(trifluoromethyl)phenyl)sulfonyl) carbamoyl)isonicotinate $21(59.5 \mathrm{mg}, 0.1 \mathrm{mmol})$ in tetrahydrofuran : water (1: $1,4 \mathrm{~mL})$, lithium hydroxide monohydrate $(15.3 \mathrm{mg}, 0.3 \mathrm{mmol})$ was added. The reaction mixture was stirred at room temperature for $18 \mathrm{~h}$. The aqueous layer was washed with dichloromethane, and then was acidified to $\mathrm{pH} 1$ using aqueous hydrochloric acid solution $(2 \mathrm{~N})$. The precipitate was separated by filtration to give $7(40.5 \mathrm{mg}, 70 \%)$ as a white solid. m.p. $252-253{ }^{\circ} \mathrm{C} ;{ }^{1} \mathrm{H}$ NMR $\left(400 \mathrm{MHz}\right.$, DMSO- $\left.d_{6}\right): \delta=8.01(\mathrm{~m}, 3 \mathrm{H}), 8.20(\mathrm{~m}$, $2 \mathrm{H}), 8.42(\mathrm{~s}, 1 \mathrm{H}), 8.85(\mathrm{~m}, 1 \mathrm{H}) ;{ }^{13} \mathrm{C} \mathrm{NMR}\left(100 \mathrm{MHz}, \mathrm{DMSO}-d_{6}\right): \delta=122.0$, $123.4\left(\mathrm{q},{ }^{1} \mathrm{~J}_{\mathrm{C}-\mathrm{F}}=271.3 \mathrm{~Hz}\right), 125.1,126.3\left(\mathrm{q},{ }^{3} \mathrm{~J}_{\mathrm{C}-\mathrm{F}}=3.7 \mathrm{~Hz}\right), 127.4,128.7$, $133.0\left(\mathrm{q},{ }^{2} \mathrm{~J}_{\mathrm{C}-\mathrm{F}}=32.2 \mathrm{~Hz}\right), 140.9,143.6,149.0,150.2,164.3(\mathrm{CONH}), 165.3$ $\left(\mathrm{CO}_{2} \mathrm{H}\right) ;{ }^{19} \mathrm{~F}$ NMR $\left(376.3 \mathrm{MHz}\right.$, DMSO-d $\left.d_{6}\right): \delta=61.65$; IR (neat) $\mathrm{u} / \mathrm{cm}^{-1}$ = 1274 (CF), 1167 (SO), 1362, 1657 (CO), 1716 (CO), 3007 (OH); MS (ESI) $\mathrm{m} / \mathrm{z}$ : calcd. for $\mathrm{C}_{14} \mathrm{H}_{8} \mathrm{~F}_{3} \mathrm{~N}_{2} \mathrm{O}_{5} \mathrm{~S}$ [M-H] : 373.0. Found 373.1; HRMS (ESI) $\mathrm{m} / \mathrm{z}$ : calcd. for $\mathrm{C}_{14} \mathrm{H}_{8} \mathrm{~F}_{3} \mathrm{~N}_{2} \mathrm{O}_{5} \mathrm{~S}[\mathrm{M}-\mathrm{H}]$ ]: 373.0112 . Found 373.0115 .

Methyl 2-((o-tolylsulfonyl)carbamoyl)isonicotinate (22). To a suspension of 4-(methoxycarbonyl)picolinic acid $17(280 \mathrm{mg}, 1.5 \mathrm{mmol})$ in dichloromethane $(5 \mathrm{~mL})$, triethylamine $(549 \mathrm{mg}, 5.4 \mathrm{mmol})$, 1hydroxybenzotriazole hydrate $(314 \mathrm{mg}, 2.3 \mathrm{mmol})$, 1-(3-dimethylaminopropyl)-3-ethylcarbodiimide hydrochloride $(441 \mathrm{mg}$, $2.3 \mathrm{mmol}$ ) were added sequentially at room temperature. The reaction was stirred at room temperature for 30 minutes. Then o-toluenesulfonamide (292 mg, $1.7 \mathrm{mmol}$ ) was added. The reaction mixture was stirred at room temperature for $48 \mathrm{~h}$. The reaction mixture was then diluted with dichloromethane, and washed by citric acid aqueous solution (10\%). The organic layer was neutralized by aqueous saturated $\mathrm{NaHCO}_{3}$ solution and dried over anhydrous $\mathrm{Na}_{2} \mathrm{SO}_{4}$. Then the solvent was removed in vacuo and the residue was purified by flash column chromatography (dichloromethane / methanol $10: 1$ ). The fractions collected were further purified by triturating with $n$-hexane-isopropanol and the precipitate was separated by filtration to give $22(70.9 \mathrm{mg}, 13 \%)$ as a white solid. $R_{f}=0.60$ (dichloromethane/methanol 4 : 1); m.p. $265-266{ }^{\circ} \mathrm{C}$; ${ }^{1} \mathrm{H}$ NMR $(400 \mathrm{MHz}$, DMSO-d $\left.d_{6}\right): \delta=2.53\left(\mathrm{~s}, 3 \mathrm{H} ; \mathrm{CH}_{3}\right), 3.89\left(\mathrm{~s}, 3 \mathrm{H} ; \mathrm{CO}_{2} \mathrm{CH}_{3}\right), 7.16-7.18(\mathrm{~m}, 1 \mathrm{H})$,
7.22-7.32 (m, 2H), 7.89-7.90 (m, 1H), $7.94(\mathrm{dd}, J=4.8,1.4 \mathrm{~Hz}, 1 \mathrm{H}), 8.45$ $(\mathrm{m}, 1 \mathrm{H}), 8.87(\mathrm{~d}, J=4.7 \mathrm{~Hz}, 1 \mathrm{H}) ;{ }^{13} \mathrm{C}$ NMR $\left(100 \mathrm{MHz}\right.$, DMSO- $\left.\mathrm{d}_{6}\right): \delta=20.1$ $\left(\mathrm{CH}_{3}\right), 52.3\left(\mathrm{CO}_{2} \mathrm{CH}_{3}\right), 123.3,124.8,125.5,128.4,129.9,130.9,135.7$, 143.9, 147.5, 147.9, 149.9, $165.2(\mathrm{CONH}), 166.5\left(\mathrm{CO}_{2} \mathrm{CH}_{3}\right)$; IR (neat) $\mathrm{u} / \mathrm{cm}^{-1}=1175$ (SO), 1349, 1709 (CO); MS (ESI-) m/z: calcd. for $\mathrm{C}_{15} \mathrm{H}_{13} \mathrm{~N}_{2} \mathrm{O}_{5} \mathrm{~S}[\mathrm{M}-\mathrm{H}]:$ : 333.0. Found 333.1.

2-((o-Tolylsulfonyl)carbamoyl)isonicotinic acid (8). To a solution of methyl 2-((o-tolylsulfonyl)carbamoyl)isonicotinate $22(49 \mathrm{mg}, 0.1 \mathrm{mmol})$ in tetrahydrofuran : water $(1: 1,8 \mathrm{~mL})$, lithium hydroxide monohydrate $(12.2$ $\mathrm{mg}, 0.2 \mathrm{mmol}$ ) was added. The reaction mixture was stirred at room temperature for $10 \mathrm{~h}$. The aqueous layer was washed with dichloromethane, and then was acidified to $\mathrm{pH} 1$ using aqueous hydrochloric acid solution $(2 \mathrm{~N})$. The precipitate was separated by filtration to give $8(23.7 \mathrm{mg}, 51 \%)$ as a white solid. m.p. $246-247{ }^{\circ} \mathrm{C} ;{ }^{1} \mathrm{H}$ NMR $(400$ $\mathrm{MHz}$, DMSO- $\left.d_{6}\right): \delta=2.61\left(\mathrm{~s}, 3 \mathrm{H} ; \mathrm{CH}_{3}\right), 7.40-7.47(\mathrm{~m}, 2 \mathrm{H}), 7.60(\mathrm{~m}, 1 \mathrm{H})$, $7.97(\mathrm{~m}, 1 \mathrm{H}), 7.98(\mathrm{~m}, 1 \mathrm{H}), 8.43(\mathrm{~m}, 1 \mathrm{H}), 8.86(\mathrm{~m}, 1 \mathrm{H}) ;{ }^{13} \mathrm{C}$ NMR $(100 \mathrm{MHz}$, DMSO- $\left.d_{6}\right): \delta=19.6\left(\mathrm{CH}_{3}\right), 122.6,124.9,126.2,130.4,132.4,133.7,137.1$, 137.2, 140.1, 149.2, 150.5, $163.6(\mathrm{CONH}), 165.4\left(\mathrm{CO}_{2} \mathrm{H}\right)$; IR (neat) $\mathrm{u} / \mathrm{cm}^{-1}$ = 1149 (SO), 1342, 1638 (CO), 1651 (CO), $\left.3006(\mathrm{OH}) ; \mathrm{MS}_{(\mathrm{ESI})}\right) \mathrm{m} / \mathrm{z}$ : calcd. for $\mathrm{C}_{14} \mathrm{H}_{11} \mathrm{~N}_{2} \mathrm{O}_{5} \mathrm{~S}[\mathrm{M}-\mathrm{H}]$ : 319.0 . Found 319.1; HRMS (ESI) $\mathrm{m} / \mathrm{z}$ : calcd. for $\mathrm{C}_{14} \mathrm{H}_{11} \mathrm{~N}_{2} \mathrm{O}_{5} \mathrm{~S}$ [M-H]: 319.0394 . Found 319.0934.

\section{Plasmid and thermal tag construction}

DNA fragments encoding full length human FTO and $\mathrm{N}$-terminally truncated ALKBH5 (residues 66-292) were cloned into pNIC28-Bsa4 to generate $\mathrm{N}$-terminal His6-tagged $\mathrm{FTO}_{1-505}$ and $\mathrm{N}$-terminal His6-tagged ALKBH566-292 constructs, respectively, as previously described. [53,55] DNA for full length human ALKBH3 was cloned into $\mathrm{pET} 28 \mathrm{a}$ to generate an $\mathrm{N}$-terminal His6-tagged ALKBH31-286 construct, as previously described. [56] The above constructs were then subjected to mutagenesis experiments using the QuikChange mutagenesis kit (Agilent Technologies) whereby DNA encoding various the KE and RD tag sequences (commercially synthesised by GenScript USA) were fused to the C-terminus of the respective genes. The sequences of all of fusion protein constructs were confirmed by DNA sequencing.

\section{Protein expression and purification}

Full length human FTO, ${ }^{477,53,55]}$ human ALKBH3, ${ }^{[56]}$ human ALKBH566-292, ${ }^{[53,55]}$ human ALKBH256-258 ${ }^{[46,53,56]}$ and human JMJD2A ${ }_{1-359}{ }^{[53]}$ was expressed and purified as previously reported, with modifications. In brief, all the constructs for the proteins and their KE/RD tagged fusion proteins were transformed into E. coli BL21 (DE3) Rosetta cells. The transformed cells were grown at $37^{\circ} \mathrm{C}$ until an OD600 of 0.6 was reached. Protein expression was then induced with isopropyl $\beta$-D-1-thiogalactopyranoside (IPTG, $0.5 \mathrm{mM}$, Gold Biotechnology). Cell growth was continued at $16{ }^{\circ} \mathrm{C}$ for $16 \mathrm{~h}$, after which the cells were harvested by centrifugation and the resulting cell pellet was stored at $-80^{\circ} \mathrm{C}$. The frozen cell pellets were then thawed, resuspended in lysis buffer and disrupted by French Press. Further purification of the protein was achieved using $\mathrm{Ni}$ affinity chromatography and gel filtration, as described below. Full length human FTO was sub-cloned into pNIC28-Bsa4 to generate a His6-tagged FTO ${ }_{1-505}$ construct. FTO in lysis buffer $(25 \mathrm{mM}$ Tris, $\mathrm{pH} 7.5,500 \mathrm{mM} \mathrm{NaCl}, 40 \mathrm{mM}$ imidazole and $5 \mathrm{mM}$ $\beta$-mercaptoethanol ( $\beta$-ME) was purified using $\mathrm{Ni}$ affinity chromatography (GE healthcare), followed by gel filtration using HiLoad superdex 200 26/60 (GE healthcare) into the final buffer (25 mM Tris buffer, pH 7.5, 100 $\mathrm{mM} \mathrm{NaCl}, 5 \%(\mathrm{v} / \mathrm{v})$ glycerol and $5 \mathrm{mM} \beta-\mathrm{ME})$. Full length ALKBH3 was sub-cloned into $\mathrm{pET} 28$ a to generate a His6-tagged ALKBH31-286 construct. ALKBH3 in lysis buffer (50 mM Sodium Phosphate, pH 8.0, $300 \mathrm{mM} \mathrm{NaCl}$, $10 \mathrm{mM}$ imidazole and $5 \mathrm{mM} \quad \beta-\mathrm{ME}$ ) was purified using $\mathrm{Ni}$ affinity chromatography (GE healthcare), followed by gel filtration using a HiLoad superdex 75 16/60 (GE healthcare) into the final buffer ( $25 \mathrm{mM}$ Sodium 
Phosphate buffer, $\mathrm{pH} 8.0,150 \mathrm{mM} \mathrm{NaCl}, 5 \%$ (v/v) glycerol and $5 \mathrm{mM}$ $\beta-M E)$. For human ALKBH5, a His6-tagged ALKBH566-292 construct in pNIC28-Bsa4 was used. ALKBH5 in lysis buffer $(20 \mathrm{mM}$ Tris, pH 8.0, $500 \mathrm{mM} \mathrm{NaCl}, 40 \mathrm{mM}$ imidazole and $5 \mathrm{mM} \beta$-ME) was first purified using $\mathrm{Ni}$ affinity chromatography (GE healthcare), followed by anion chromatography using a $5 \mathrm{~mL}$ HiTrap Q HP column (GE healthcare) and gel filtration using HiLoad superdex $7516 / 60$ (GE healthcare) into the final buffer (20 mM Tris buffer, $\mathrm{pH} 8.0,100 \mathrm{mM} \mathrm{NaCl}$ and $5 \mathrm{mM} \beta$-ME). For human ALKBH2, a His6-tagged ALKBH256-258 construct in pET28b was used. ALKBH2 in lysis buffer ( $50 \mathrm{mM}$ Sodium Phosphate buffer, $\mathrm{pH} 8.0$, $300 \mathrm{mM} \mathrm{NaCl}, 10 \%$ (v/v) glycerol, $5 \mathrm{mM} \beta-\mathrm{ME}$ ) was purified by Ni affinity chromatography (GE healthcare), followed by anion chromatography using a $5 \mathrm{~mL}$ HiTrap Q HP column (GE healthcare) and gel filtration using a HiLoad superdex 75 26/60 (GE healthcare) into a final buffer of $10 \mathrm{mM}$ Tris, pH 8.0, $100 \mathrm{mM} \mathrm{NaCl}, 5 \mathrm{mM} \beta$-ME. For human JMJD2A, a His6-tagged JMJD2A 1-359 construct in pNIC28-Bsa4 was used. The transformed E.coli cells were grown in Terrific Broth (TB) supplemented with $8 \mathrm{~g} / \mathrm{L}$ of glycerol and appropriate antibiotics. JMJD2A in lysis buffer containing $100 \mathrm{mM}$ HEPES, $500 \mathrm{mM} \mathrm{NaCl}, 10 \mathrm{mM}$ Imidazole, $10 \%$ glycerol, 0.5 mM TCEP, pH 8.0, Benzonase, Protease Inhibitor Cocktail Set III was purified using Ni-NTA Superflow (Qiagen) column followed by HiLoad 16/60 Superdex-200 column (GE Healthcare) into a final buffer of $20 \mathrm{mM}$ HEPES, pH 7.5, $300 \mathrm{mM} \mathrm{NaCl}, 10 \%$ (v/v) glycerol, $0.5 \mathrm{mM}$ TCEP. All $\mathrm{KE} / \mathrm{RD}$ tagged proteins were expressed using similar methods. For details, see Supporting Information.

\section{Differential Scanning Fluorimetry (DSF) melting analysis}

All DSF-based experiments were performed using a MiniOpticon RealTime PCR Detection System (Bio-Rad), monitoring protein unfolding using SYPRO orange (Invitrogen) according to the reported method. ${ }^{[43,53]}$ To characterise the effects of thermal tags on the melting temperature $\left(T_{m}\right)$ of proteins:

The reaction mixtures contained proteins $(2 \mu \mathrm{M}), \mathrm{MnCl}_{2}(50 \mu \mathrm{M}$; active site metal) and 5x SYPRO orange (Invitrogen; fluorescent dye) in a final volume of $50 \mu \mathrm{L}$. Reagents were prepared in $50 \mathrm{mM}$ HEPES buffer, $\mathrm{pH}$ 6.0 except $\mathrm{MnCl}_{2}$, which was dissolved as $100 \mathrm{mM}$ stocks in $20 \mathrm{mM} \mathrm{HCl}$, then further diluted in MilliQ water. Fluorescence were detected on FAM channel, with readings taken every $0.5^{\circ} \mathrm{C}$ in the range $25-95^{\circ} \mathrm{C}$, with the temperature increased linearly by $1^{\circ} \mathrm{C} / \mathrm{min}$. The fluorescence intensity data was then fitted to Boltzmann Sigmoidal curve using GraphPad Prism 6.0 to determine melting temperature $\left(T_{\mathrm{m}}\right)$ of the proteins. The $T_{\mathrm{m}}$ shift caused by the thermal tags was determined by subtraction of the $T_{\mathrm{m}}$ of untagged protein from the $T_{\mathrm{m}}$ of fusion protein. The assay was performed in triplicate for each protein, with standard deviations typically $<1{ }^{\circ} \mathrm{C}$.

For thermal shift assay with inhibitors:

The reaction mixtures contained proteins $(2 \mu \mathrm{M}), \mathrm{MnCl}_{2}(50 \mu \mathrm{M})$, compounds $(100 \mu \mathrm{M})$ and $5 \mathrm{x}$ SYPRO in a final volume of $50 \mu \mathrm{L}$. The inhibitors tested were prepared in $100 \%$ DMSO and added such that the final concentration of DMSO was not more than $1 \% \mathrm{v} / \mathrm{v}$ of assay mix. The $T_{\mathrm{m}}$ was determined as described above. The $T_{\mathrm{m}}$ shift caused by the addition of each inhibitor was determined by subtraction of the 'reference' $T_{\mathrm{m}}$ (derived from protein incubated with $\mathrm{MnCl}_{2}$ and $1 \% \mathrm{v} / \mathrm{v} \mathrm{DMSO}$ ) from the $T_{\mathrm{m}}$ obtained in the presence of the inhibitor. The assay was performed in triplicate for each inhibitor, with standard deviations typically $<1{ }^{\circ} \mathrm{C}$.

\section{Circular dichroism (CD) spectroscopy}

The proteins were exchanged into $10 \mathrm{mM}$ sodium phosphate buffer $(\mathrm{pH}$ 6.0). Far UV-CD spectra were recorded at a protein concentration of 0.1 $\mathrm{mg} / \mathrm{mL}$ at $25^{\circ} \mathrm{C}$ on a JASCO J-810 spectropolarimeter over a wavelength range of $190-250 \mathrm{~nm}$ with a scan rate of $20 \mathrm{~nm} / \mathrm{min}$. All the spectra were subtracted with the buffer blank and smoothed using the Savitsky-Golay algorithm (polynomial order 10). All measurements were performed in triplicates.
Steady-state kinetic analyses of nucleic acid demethylation by untagged ALKB proteins and their tagged counterparts

Steady-state kinetic analysis is done using HPLC-based demethylation assays. The substrates used are $5^{\prime}-\mathrm{GG}\left(\mathrm{m}^{6} \mathrm{~A}\right) \mathrm{CU}-3^{\prime}$ (for $\mathrm{FTO}$ ); 5'-AAAGCAG $\left(\mathrm{m}^{1} \mathrm{~A}\right) \mathrm{ATTCGAA}-3^{\prime}$ (for ALKBH3) and 5'-GG( $\left.\mathrm{m}^{6} \mathrm{~A}\right) \mathrm{CU}-3^{\prime}$ ' (for ALKBH5). The $K_{\mathrm{m}}$ and $k_{\text {cat }}$ values were determined by keeping a constant enzyme concentration of $0.5 \mu \mathrm{M}$ and varying the substrate concentrations $(0.5,1,2,3,5$ and $10 \mu \mathrm{M})$, as previously reported. ${ }^{[53]}$ The concentration of demethylated product at different substrate concentrations was plotted as a function of time. The initial velocity $\left(V_{0}\right)$ for each substrate concentration was determined from the slope of the curve at the beginning of a reaction. The Michaelis-Menten curve was fitted using non-linear regression, and the kinetic constants $\left(V_{\max }, K_{\mathrm{m}}\right)$ of the substrate was estimated using GraphPad Prism 6.0. All reactions were performed at $4{ }^{\circ} \mathrm{C}$ in triplicate and were adjusted to ensure that less than $20 \%$ of the substrate was consumed.

\section{Multi-protein DCC approach}

The dynamic library was constituted by mixing ALKBH5-KE6 $(2 \mu \mathrm{M})$, FTOKE12 $(2 \mu \mathrm{M})$, ALKBH3-KE18 $(2 \mu \mathrm{M})$, scaffold ligand $3(40 \mu \mathrm{M})$, aldehydes 4a-j (library A, each aldehyde at $20 \mu \mathrm{M}), \mathrm{MnCl}_{2}(50 \mu \mathrm{M})$ and aniline $(5 \mathrm{mM})$ in HEPES buffer $(50 \mathrm{mM}, \mathrm{pH} 6.0)$ in a final reaction volume of $50 \mu \mathrm{L}$. The reaction was incubated at $25^{\circ} \mathrm{C}$ for the specified time points (see Figure 5 ), after which SYPRO orange ( $5 x$; Invitrogen) was added, and the reaction mixture analysed using a MiniOpticon ${ }^{\mathrm{TM}}$ Real-Time PCR Detection System (Bio-Rad). Melting curve was obtained by steady heating from $25^{\circ} \mathrm{C}$ to $95^{\circ} \mathrm{C}$ at a rate of $1{ }^{\circ} \mathrm{C} / \mathrm{min}$. Fluorescence were detected on FAM channel, with readings taken every $0.5^{\circ} \mathrm{C}$. The fluorescence intensity data was then fitted to Boltzmann Sigmoidal curve using GraphPad Prism 6.0 to determine melting temperature $\left(T_{\mathrm{m}}\right)$ of the proteins. The assay was performed in triplicate, with standard deviations typically $<1{ }^{\circ} \mathrm{C}$.

\section{HPLC analysis of multi-protein DCC}

The DCL was analysed using a Zorbax C18 column $(4.6 \mathrm{~mm} \times 250 \mathrm{~mm}$ ) at a flow rate of $1 \mathrm{~mL} / \mathrm{min}$ at $25{ }^{\circ} \mathrm{C}$. Gradient used: from $95 \%$ solvent $A$ (water + $0.1 \%$ TFA) to $15 \%$ solvent $\mathrm{B}(\mathrm{MeOH})$ over $20 \mathrm{~min}$, then to $60 \%$ solvent B over $30 \mathrm{~min}$. The UV detection wavelength was set at $254 \mathrm{~nm}$. The concentration of adducts $\mathbf{5 e}$ and $\mathbf{5} \boldsymbol{h}$ were calculated based on their peak areas, using calibration plots obtained from pure standards. The percentages of adduct formation were calculated relative to the starting concentration of scaffold ligand $3(40 \mu \mathrm{M})$.

\section{NMR water relaxation experiment}

NMR assay was performed as previously reported, with modifications. ${ }^{[14,65]}$ The experiments were conducted at $500 \mathrm{MHz}$ using a Bruker DRX 500 spectrometer equipped with a standard $5 \mathrm{~mm}$ z-gradient TXI probe. Unless otherwise stated, all experiments were conducted at $298 \mathrm{~K}$ in conventional $3 \mathrm{~mm}$ diameter NMR tube (Norell). A freshly prepared mixture of protein $(50 \mu \mathrm{M}), \mathrm{Mn}(\mathrm{II})(50 \mu \mathrm{M})$ and aldehyde $(500 \mu \mathrm{M})$ buffered with $50 \mathrm{mM}$ Tris dissolved in $10 \% \mathrm{H}_{2} \mathrm{O}$ and $90 \% \mathrm{D}_{2} \mathrm{O}(\mathrm{pH} 6.0)$ was titrated against scaffold ligand 3 at varying concentrations $(10,25,50,80,100 \mu \mathrm{M})$. A 1:1 molar ratio of protein to $\mathrm{Mn}(\mathrm{II})$ was used to minimise any contribution to relaxation rate changes from binding of small molecules to free $\mathrm{Mn}(\mathrm{II})$. Inversion recovery experiments were performed with two scans with a relaxation delay of at least 5 times $T_{1}$ (longitudinal relaxation time constants) between transients. Pulse tip-angle calibration using the single-pulse nutation method was undertaken for each sample ensuring accurate $90^{\circ}$ and $180^{\circ}$ pulses. The data were plotted as the fractional change in relaxation rate (1 - $\left.R_{1} / R_{1(0)}\right)$ against ligand concentration. $K_{D}$ curves were fitted using GraphPad Prism 6.0.The assay was performed in triplicate. 


\section{Acknowledgements}

This research was supported by grants from the Singapore Ministry of Health's National Medical Research Council (NMRC/BNIG/2008/2013) and the Singapore Ministry of Education (AcRF Tier 1 Grant R148-000-231-114 and R148-000238-114).

Keywords: Drug discovery • Dynamic combinatorial chemistry - Epigenetics $•$ Nucleic acid demethylases $•$ Selective inhibitors

[1] P. T. Corbett, J. Leclaire, L. Vial, K. R. West, J. L. Wietor, J. K. M. Sanders, S. Otto, Chem. Rev. 2006, 106, 3652-3711.

[2] J.-M. Lehn, J.-M. Lehn, Chem. Soc. Rev. 2007, 36, 151-160.

[3] O. Ramström, L. Amorim, R. Caraballo, O. Norberg in Dynamic Combinatorial Chemistry, (Eds.: J. N. Reek, S. Otto), Wiley-VCH, Weinheim, 2010, pp 109-150.

[4] O. Ramström, J.-M. Lehn, Nat. Rev. Drug Discov. 2002, 1, 26-36.

[5] M. Mondal, A. K. H. Hirsch, Chem. Soc. Rev. 2015, 44, 2455-2488.

[6] C. Karan, B. L. Miller, Drug Discov. Today 2000, 5, 67-75.

[7] A. Herrmann, Chem. Soc. Rev. 2014, 43, 1899-1933.

[8] R. van der Vlag, A. K. H. Hirsch, Analytical Methods in Protein-Templated Dynamic Combinatorial Chemistry, in Comprehensive Supramolecular Chemistry II, (Eds.: J. L. Atwood), Elsevier, Amsterdam, 2017, pp 487-509.

[9] R. Huang, I. K. H. Leung, Molecules 2016, 21, 910.

[10] M. Jaegle, E. L. Wong, C. Tauber, E. Nawrotzky, C. Arkona, J. Rademann, Angew. Chemie - Int. Ed. 2017, 56, 7358-7378.

[11] M. Mondal, N. Radeva, H. Köster, A. Park, C. Potamitis, M. Zervou, G. Klebe, A. K. H. Hirsch, Angew. Chemie Int. Ed. 2014, 53, 3259-3263.

[12] E. C. Y. Woon, M. Demetriades, E. A. L. Bagg, W. Aik, S. M. Krylova, J. H. Y. Ma, M. Chan, L. J. Walport, D. W. Wegman, K. N. Dack, M. A. McDonough, S. N. Krylov, C. J. Schofield, J. Med. Chem. 2012, 55, 2173-2184.

[13] N. R. Rose, E. C. Y. Woon, G. L. Kingham, O. N. F. King, J. Mecinović, I. J. Clifton, S. S. Ng, J. Talib-Hardy, U. Oppermann, M. A. McDonough, C. J. Schofield, J. Med. Chem. 2010, 53, 1810-1818.

[14] M. Demetriades, I. K. H. Leung, R. Chowdhury, M. C. Chan, M. A. McDonough, K. K. Yeoh, Y. M. Tian, T. D. W. Claridge, P. J. Ratcliffe, E. C. Y. Woon, C. J. Schofield, Angew. Chemie - Int. Ed. 2012, 51, 6672-6675.

[15] B. L. Miller in Constitutional Dynamic Chemistry: Topics in Current Chemistry, (Eds.: M. Barboiu), Springer, Berlin, Heidelberg, 2012, pp 107-137. [16] C. S. Mahon, D. A. Fulton, Nat. Chem. 2014, 6, 665-672.

[17] B. P. Benke, P. Aich, Y. Kim, K. L. Kim, M. R. Rohman, S. Hong, I. C Hwang, E. H. Lee, J. H. Roh, K. Kim, J. Am. Chem. Soc. 2017, 139, 7432-7435. [18] V. T. Bhat, A. M. Caniard, T. Luksch, R. Brenk, D. J. Campopiano, M. F. Greaney, Nat. Chem. 2010, 2, 490-497.

[19] M. C. Misuraca, E. Moulin, Y. Ruff, N. Giuseppone, New J. Chem. 2014, 38, 3336-3349.

[20] S. Zameo, B. Vauzeilles, J. M. Beau, European J. Org. Chem. 2006, 2006 5441-5444.

[21] L. Roy, M. A. Case, J. Phys. Chem. B 2011, 115, 2454-2464.

[22] M. Dal Molin, G. Gasparini, P. Scrimin, F. Rastrelli, L. J. Prins, Chem. Commun. 2011, 47, 12476.

[23] Y. Cohen, L. Avram, L. Frish, Angew. Chemie - Int. Ed. 2005, 44, 520-554. [24] K. K. Larson, M. He, J. F. Teichert, A. Naganawa, J. W. Bode, Chem. Sci. 2012, 3, 1825-1828.

[25] M. S. Congreve, D. J. Davis, L. Devine, C. Granata, M. O’Reilly, P. G. Wyatt, H. Jhoti, Angew. Chemie - Int. Ed. 2003, 42, 4479-4482.

[26] J. F. Tolmer-Andersen, J. M. Lehn, Angew. Chemie - Int. Ed. 2009, 48, 7664-7667

[27] D. A. Fulton, Org. Lett. 2008, 10, 3291-3294.

[28] C. S. Mahon, M. A. Fascione, C. Sakonsinsiri, T. E. McAllister, W. Bruce Turnbull, D. A. Fulton, Org. Biomol. Chem. 2015, 13, 2756-2761.
[29] F. V. Reddavide, W. Lin, S. Lehnert, Y. Zhang, Angew. Chemie - Int. Ed. 2015, 54, 7924-7928.

[30] J. P. Daguer, M. Ciobanu, S. Alvarez, S. Barluenga, N. Winssinger, Chem Sci. 2011, 2, 625-632.

[31] Z. Kanlidere, O. Jochim, M. Cal, U. Diederichsen, Beilstein J. Org. Chem. 2016, 12, 2136-2144

[32] G. Li, W. Zheng, Z. Chen, Y. Zhou, Y. Liu, J. Yang, Y. Huang, X. Li, Chem. Sci. 2015, 6, 7097-7104.

[33] M. Egholm, O. Buchardt, L. Christensen, C. Behrens, S. M. Freier, D. A. Driver, R. H. Berg, S. K. Kim, B. Norden, P. E. Nielsen, Nature 1993, 365, 566 568.

[34] H. D. Urbina, F. Debaene, B. Jost, C. Bole-Feysot, D. E. Mason, P. Kuzmic, J. L. Harris, N. Winssinger, ChemBioChem 2006, 7, 1790-1797.

[35] J. M. Daniel, S. D. Friess, S. Rajagopalan, S. Wendt, R. Zenobi, Int. J. Mass Spectrom. 2002, 216, 1-27

[36] S.-A. Poulsen, J. Am. Soc. Mass Spectrom. 2006, 17, 1074-1080.

[37] S. Jiang, Z. Cao, Adv. Mater. 2010, 22, 920-932.

[38] L. Zheng, H. S. Sundaram, Z. Wei, C. Li, Z. Yuan, React. Funct. Polym. 2017, 118, 51-61.

[39] L. Mi, S. Jiang, Angew. Chemie - Int. Ed. 2014, 53, 1746-1754.

[40] P. Zhang, F. Sun, C. Tsao, S. Liu, P. Jain, A. Sinclair, H.-C. Hung, T. Bai, K. Wu, S. Jiang, Proc. Natl. Acad. Sci. 2015, 112, 12046-12051.

[41] A. J. Keefe, S. Jiang, Nat. Chem. 2011, 4, 59-63.

[42] E. J. Liu, A. Sinclair, A. J. Keefe, B. L. Nannenga, B. L. Coyle, F. Baneyx, S. Jiang, Biomacromolecules 2015, 16, 3357-3361.

[43] F. H. Niesen, H. Berglund, M. Vedadi, Nat. Protoc. 2007, 2, 2212-2221.

[44] A. Thalhammer, W. Aik, E. A. L. Bagg, C. J. Schofield, Drug Discov. Today Ther. Strateg. 2012, 9, e91-e100.

[45] S. C. Trewick, T. F. Henshaw, R. P. Hausinger, T. Lindahl, B. Sedgwick, Nature 2002, 419, 174-178.

[46] C.-G. Yang, C. Yi, E. M. Duguid, C. T. Sullivan, X. Jian, P. A. Rice, C. He, Nature 2008, 452, 961-965.

[47] G. Jia, Y. Fu, X. Zhao, Q. Dai, G. Zheng, Y. Yang, C. Yi, T. Lindahl, T. Pan, Y.-G. Yang, C. He, Nat. Chem. Biol. 2011, 7, 885-887.

[48] G. Zheng, J. A. Dahl, Y. Niu, P. Fedorcsak, C. M. Huang, C. J. Li, C. B. Vågbø, Y. Shi, W. L. Wang, S. H. Song, Z. Lu, R. P. Bosmans, Q. Dai, Y. J. Hao, X. Yang, W. M. Zhao, W. M. Tong, X. J. Wang, F. Bogdan, K. Furu, Y. Fu, G. Jia, X. Zhao, J. Liu, H. E. Krokan, A. Klungland, Y. G. Yang, C. He, Mol. Cell 2013, 49, 18-29.

[49] T. M. Frayling, N. J. Timpson, M. N. Weedon, E. Zeggini, R. M. Freathy, C M. Lindgren, J. R. B. Perry, K. S. Elliott, H. Lango, N. W. Rayner, B. Shields, L. W. Harries, J. C. Barrett, S. Ellard, C. J. Groves, B. Knight, A. M. Patch, A. R. Ness, S. Ebrahim, D. A. Lawlor, S. M. Ring, Y. Ben-Shlomo, M. R. Jarvelin, U. Sovio, A. J. Bennett, D. Melzer, L. Ferrucci, R. J. Loos, I. Barroso, N. J. Wareham, F. Karpe, K. R. Owen, L. R. Cardon, M. Walker, G. A. Hitman, C. N. Palmer, A. S. Doney, A. D. Morris, G. D. Smith, A.T. Hattersley, M. I. McCarthy, Science 2007, 316, 889-894.

[50] K. Koike, Y. Ueda, H. Hase, K. Kitae, Y. Fusamae, S. Masai, T. Inagaki, Y. Saigo, S. Hirasawa, K. Nakajima, I. Ohshio, Y. Makino, N. Konishi, H. Yamamoto, K. Tsujikawa, Curr. Cancer Drug Targets 2012, 12, 847-856.

[51] A. Lim, J. Zhou, R. A. Sinha, B. K. Singh, S. Ghosh, K. H. Lim, P. K. H. Chow, E. C. Woon, P. M. Yen, Biochem. Biophys. Res. Commun. 2016, 479, 476-481.

[52] W. Aik, J. S. Scotti, H. Choi, L. Gong, M. Demetriades, C. J. Schofield, M. A. McDonough, Nucleic Acids Res. 2014, 42, 4741-4754.

[53] J. D. W. Toh, L. Sun, L. Z. M. Lau, J. Tan, J. J. A. Low, C. W. Q. Tang, E. J. Y. Cheong, M. J. H. Tan, Y. Chen, W. Hong, Y.-G. Gao, E. C. Y. Woon, Chem. Sci. 2015, 6, 112-122.

[54] O. Sundheim, C. B. Vågbø, M. Bjørås, M. M. L. Sousa, V. Talstad, P. A. Aas, F. Drabløs, H. E. Krokan, J. A. Tainer, G. Slupphaug, EMBO J. 2006, 25, 3389-3397.

[55] S. Zou, J. D. W. Toh, K. H. Q. Wong, Y.-G. Gao, W. Hong, E. C. Y. Woon, Sci. Rep. 2016, 6, 25677.

[56] T. Yang, A. Cheong, X. Mai, S. Zou, E. C. Y. Woon, Chem. Commun. 2016, $52,6181-6184$. 
[57] N. R. Rose, E. C. Y. Woon, A. Tumber, L. J. Walport, R. Chowdhury, X. S. Li, O. N. F. King, C. Lejeune, S. Ng, T. Krojer, M. C. Chan, A. M. Rydzik, R. J. Hopkinson, K. H. Che, M. Daniel, C. Strain-Damerell, C. Gileadi, G. Kochan, I. K. Leung, J. Dunford, K. K. Yeoh, P. J. Ratcliffe, N. Burgess-Brown, F. von Delft, S. Muller, B. Marsden, P. E. Brennan, M. A. McDonough. U. Oppermann, R. J. Klose, C. J. Schofield, A. Kawamura, J. Med. Chem. 2012, 55, 6639-643. [58] G. R. L. Cousins, S.-A. Poulsen, J. K. M. Sanders, Chem. Commun. 1999, 1575-1576.

[59] R. Nguyen and Ivan Huc, Chem. Commun. 2003, 942.

[60] B. Levrand, Y. Ruff, J.-M. Lehn, A. Herrmann, Chem. Commun. 2006, 29652967.

[61] E. H. Cordes, W. P. Jencks, J. Am. Chem. Soc. 1962, 84, 826-831.
[62] I. K. H. Leung, E. Flashman, K. K. Yeoh, C. J. Schofield, T. D. W. Claridge, J. Med. Chem. 2010, 53, 867-875.

[63] M. Sindelar, T. A. Lutz, M. Petrera, K. T. Wanner, J. Med. Chem. 2013, 56, 1323-1340.

[64] E. C. Y. Woon, A. Tumber, A. Kawamura, L. Hillringhaus, W. Ge, N. R. Rose, J. H. Y. Ma, M. C. Chan, L. J. Walport, K. H. Che, S. S. Ng, B. D. Marsden, U. Opperman, M. A. McDonough, C. J. Schofield, Angew. Chemie Int. Ed. 2012 51, 1631-1634.

[65] I. K. H. Leung, M. Demetriades, A. P. Hardy, C. Lejeune, T. J. Smart, A Szöllössi, A. Kawamura, C. J. Schofield, T. D. W. Claridge, J. Med. Chem. 2013, $56,547-555$ 


\section{Entry for the Table of Contents}

Layout 2:

\section{FULL PAPER}

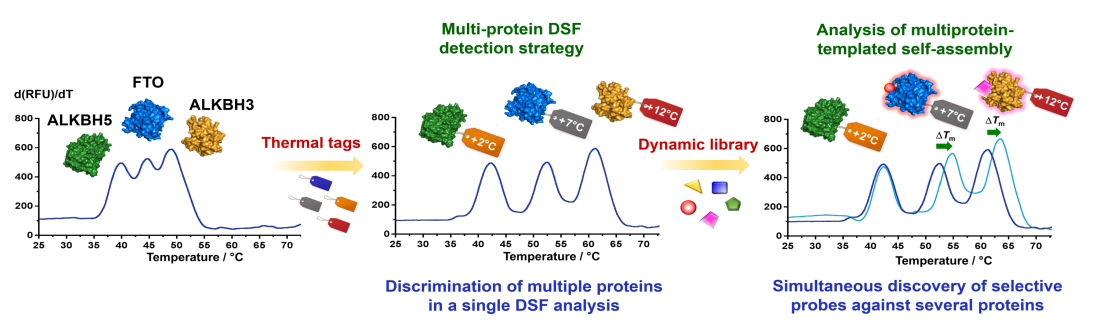

Mohua Das, Tianming Yang, Jinghua Dong, Fransisca Prasetya, Yiming Xie, Kendra H. Q. Wong, Adeline Cheong, and Esther C. Y. Woon*

Page No. - Page No.

Multi-Protein Dynamic

Combinatorial Chemistry: A Novel Strategy that Leads to Simultaneous Discovery of Subfamily-Selective Inhibitors for Nucleic Acid Demethylases FTO and ALKBH3

A novel multi-protein DSF strategy which uses thermal tag to exclusively fine-tune the melting temperature of the target proteins such that their individual melting profiles could be monitored in a single DSF melting analysis. When combined with DCC, formation of protein-ligand complexes can be detected by shifts in $T_{\mathrm{m}}$ of proteins engaged in ligand binding. This strategy led to the discovery of selective ligands for FTO and ALKBH3 simultaneously. 